\title{
Historia dwudziestowiecznych prześladowań Rosyjskiego Kościoła Prawosławnego przedstawiona na ikonie Soboru Świętych Nowych Męczenników i Wyznawców Rosyjskich ${ }^{1}$
}

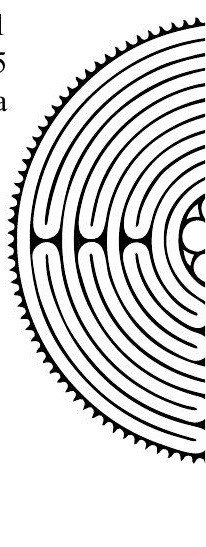

\author{
Marta Łukaszewicz \\ Instytut Rusycystyki \\ Uniwersytet Warszawski \\ Zuzanna Bogumit \\ Instytut Filozofii i Socjologii \\ Akademia Pedagogiki Specjalnej im. Marii Grzegorzewskiej w Warszawie
}

\begin{abstract}
The History of the Twentieth-Century Persecutions against the Russian Orthodox Church as Depicted on the Icon of the New Martyrs and Confessors of the Russian Church
\end{abstract}

The paper analyses the concept of "the new martyrdom" functioning today in the Russian Orthodox Church. Through this prism, presented on the icon of the New Martyrs and Confessors of Russian Church, we examine the official Orthodox perception of the Soviet past, especially the period of persecutions in 1917-1937. Attention is paid to the way the historical facts are shown and to the narrative which is thus created. The authors conclude that the icon and its official description create a glorious vision of history, emphasising the uniqueness of new martyrs' testimony and abolishing questions about the cause of the revolution and the persecutors. The huge number of martyrs becomes evidence of the spiritual greatness of Russia, whereby victims are treated instrumentally, to give a spiritual meaning to the persecutions, perceived as a part of the eternal struggle between good and evil.

${ }^{1}$ Niniejszy artykuł powstał w ramach realizacji dwóch projektów finansowanych przez Narodowe Centrum Nauki: pierwszego zatytułowanego Nowe męczeństwo - prawosławna interpretacja doświadczenia represji sowieckich nr N N116 696040 (kierownik: Zuzanna Bogumił, główny wykonawca: Marta Łukaszewicz - lata 2011-2016) i drugiego zatytułowanego Od wroga ludu do świętego męczennika analiza obchodów 100-lecia Rewolucji 1917 roku i 80-lecia Wielkiego Terroru w Rosji, nr 2016/21/B/ HS6/03782 (kierownik: Zuzanna Bogumił). 
Key words: icon, Orthodoxy, new martyrdom, Russian Orthodox Church, persecutions, Soviet repressions

Słowa kluczowe: ikona, prawosławie, nowe męczeństwo, Rosyjski Kościół Prawosławny, prześladowania, represje sowieckie

Ikona wyraża duchowe doświadczenie świętości i przekazuje to tak samo prawdziwie jak rzeczywistość historyczna, dzięki temu mamy ,,dokota siebie takie mnóstwo świadków” wedtug określenia św. Pawła

(L. Uspienski, Teologia ikony, s. 138).

W dniach 25-27 stycznia 2017 roku w Moskwie odbyło się XXV Międzynarodowe Świąteczne Forum Edukacyjne (XXV Международные Рождественские образовательные чтения) przeprowadzone pod hasłem „1917-2017: уроки столетия” (,1917-2017: pokłosie stulecia”). Rezultatem forum stał się dokument opublikowany na oficjalnej stronie Patriarchatu Moskiewskiego, podpisany przez ,10 000 uczestników Forum, zgromadzonych w Moskwie, a także setki tysięcy tych, którzy wzięli w nim udział na szczeblu regionalnym"2. Stwierdzono w nim, że

[...] za głęboko ukrytą przyczynę kilku rewolucji, które doprowadziły do przejęcia władzy przez radykalne siły polityczne, bratobójczej wojny domowej, represji wobec poszczególnych osób i całych grup społecznych, cierpienia ludzi i licznych ofiar, należy uznać utratę przez społeczeństwo żywej i szczerej wiary w Boga... ${ }^{3}$

\section{Następnie podkreślono, że}

[...] ofiara nowych męczenników i wyznawców Kościoła Rosyjskiego, którzy własną krwią poświadczyli swą wierność Chrystusowi i Jego Boskiej prawdzie, stała się prawdziwie ewangeliczną odpowiedzią na bezprecedensowe prześladowania Kościoła Rosyjskiego w naszym kraju. [...] W znacznej mierze to właśnie ich czyn umożliwił odrodzenie się wiary i życia cerkiewnego w krajach podlegających odpowiedzialności kanonicznej Patriarchatu Moskiewskiego ${ }^{4}$.

Rodzą się zatem pytania: Kim są nowi męczennicy? Jak wyglądała i na czym polegała ich ewangeliczna odpowiedź na bezprecedensowe prześladowania?

W niniejszym artykule przedstawiamy prawosławną interpretację przeszłości i znaczenie dyskursu nowego męczeństwa ${ }^{5}$ dla współczesnego Kościoła prawosławnego.

${ }^{2}$ Итоговый документ XXV Международных Рождественских образовательных чтений, http://www.patriarchia.ru/db/text/4792900.html [dostęp: 1.02.2017].

${ }^{3}$ Ibidem.

${ }^{4}$ Ibidem.

5 Określenie „,nowy męczennik” czy też „nowomęczennik” („новый мученик”, później również „новомученик”) zostało zastosowane przez Święty Synod Rosyjskiego Kościoła Prawosławnego w stosunku do pierwszych ofiar reżimu bolszewickiego już na przełomie marca i kwietnia 1918 r. i weszło do powszechnego użytku m.in. dzięki książce o. Michaiła Polskiego Новые мученики российские (Nowi męczennicy rosyjscy, Jordanville 1949-1957). Nawiązuje ono do greckich nowych męczenników

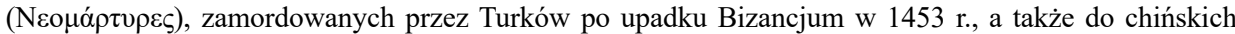
nowych męczenników, ofiar powstania bokserów, którzy zginęli w 1900 r. i już w 1902 byli kanonizowani przez Rosyjski Kościół Prawosławny jako lokalni święci. Zob. K. Каварнос, Значение новых мучеников в жизни Православной Церкви, „Православная жизнь” 1999, nr 2 (590), s. 1-12, http://petkohinov. 
Aby je lepiej zrozumieć, odwołujemy się do wydarzeń przedstawionych na ikonie Soboru Świętych Nowych Męczenników i Wyznawców Rosyjskich, napisanej i poświęconej w 2000 roku w związku z kanonizacją 1097 nowych męczenników, jaka nastąpiła w trakcie jubileuszowego Soboru Rosyjskiego Kościoła Prawosławnego. Ikonę tę traktujemy jako zamkniętą, całościową opowieść o przeszłości. Naszym celem jest pokazanie zarówno tego, jakie fakty są włączane w historię nowego męczeństwa, jak i sposobu, w jaki jest budowana narracja o niej (zarówno w wymiarze wizualnym - przedstawienie scen męczeństwa na ikonie - jak i tekstualnym, ikona posiada bowiem swój oficjalny opis). Interesują nas również informacje pominięte na ikonie, pokazują one bowiem elementy, które w prawosławnej interpretacji przeszłości są uznane za mniej ważne lub celowo tabuizowane. Zanim jednak przedstawimy wydarzenia, które w prawosławnym dyskursie nowego męczeństwa zyskują znaczenie, pokrótce omówimy historię kanonizacji nowych męczenników i najważniejsze momenty rozwoju ich kultu.

\section{Genealogia dyskursu nowego męczeństwa}

Jak pisze rosyjski badacz Ilja Semienienko-Basin, grunt pod przyszłą kanonizację nowych męczenników przygotował kult oddawany ofiarom terroru we wspólnotach wiernych, będący konsekwencją orzeczenia Soboru Rosyjskiego Kościoła Prawosławnego z 5 kwietnia 1918 roku, w którym ustalono wprowadzenie specjalnych modlitw za zmarłych $w$ wyniku prześladowań oraz wezwano do gromadzenia informacji na ich temat ${ }^{6}$. Biskupi zwrócili się z prośbą do wiernych o zbieranie materiałów o życiu i śmierci nowych męczenników, o to, aby 25 stycznia modlili się za wszystkich zamordowanych po wybuchu rewolucji księży i wiernych, którzy zginęli broniąc wiary, za „wszystkich zmarłych w obecnych straszliwych czasach prześladowań wyznawców i męczenników"7; aby organizowali pielgrzymki do ich grobów w trzecią niedzielę po Wielkanocy i aby modlili się do nich o wstawiennictwo. W roku 1949 we wstępie do książki Новые мученики российские (Nowi męczennicy rosyjscy) o. Michaił Polski napisał: „tak jasno zrozumiał nasz Święty Kościół czas, który nastał, i ocenił znaczenie śmierci pierwszych ofiar prześladowań"8.

Na wydane w latach 1949-1957 na emigracji dwutomowe dzieło o. Michaiła Polskiego zwraca uwagę Semienienko-Basin, podkreślając znaczenie tej publikacji dla kształtowania się kultu nowych męczenników. Polski wyraźnie podkreśla we wstępie do książki, że jego praca nad zbieraniem materiałów na temat życia, cierpień

com/pravoslavie/rus/11/kavarnos.html [dostęp: 11.05.2016]; И.В. Семененко-Басин, Новомученики российские: содержание термина, „Диалог со временем” 2009, nr 28, s. 368; J. Charkiewicz, Kanonizacja nowomęczenników okresu niewoli tureckiej w Kościele prawosławnym i ich znaczenie, „Elpis” 2015, nr 17, s. 43-45.

${ }^{6}$ И.В. Семененко-Басин, Святость в русской православной культуре ХХ века. История персонификации, Москва 2010, s. 53-54.

${ }^{7}$ Русская православная иерковь и коммунистическое государство 1917-1941. Документы и фотоматериаль, А. Сапов (red.), Москва 1996, s. 18.

${ }^{8}$ М. Польский, Новые Мученики Российские, t. 1, Jordanville 1949, s. 4. 
i męczeńskiej śmierci ofiar bolszewików jest realizacją wspomnianego wyżej orzeczenia Soboru Rosyjskiego Kościoła Prawosławnego z 5 kwietnia 1918 roku, w którym, oprócz wprowadzenia specjalnych modlitw za zmarłych $w$ wyniku prześladowań, wezwano do gromadzenia informacji na ich temat.

Ważne znaczenie dla ustanowienia kultu nowych męczenników miały również inne książki wydane za granicą, napisane przez rosyjskich dysydentów, przede wszystkim Трагедия русской церкви (Tragedia cerkwi rosyjskiej) Lwa Regelsona (Paryż 1977) oraz Свидетельство обвинения (Świadectwo oskarżenia) Władimira Stiepanowa (Rusaka) (Jordanville 1980).

Wszystkie te działania upamiętniające podjęto w obrębie Rosyjskiego Kościoła Prawosławnego poza Granicami Rosji, natomiast w Związku Radzieckim jawny kult ofiar prześladowań nie był możliwy i choć niektórzy duchowni w modlitwach na liturgii wspominali ich imiona, to orzeczenie Soboru wydawało się zapomniane ${ }^{9}$. Nie było na nie miejsca w oficjalnym dyskursie Rosyjskiego Kościoła Prawosławnego, zwłaszcza po deklaracji lojalności metropolity Sergiusza (Stragorodskiego), złożonej w 1927 roku, i jego oświadczeniu na konferencji prasowej z roku 1930, że ,prześladowania religii w ZSRR żadnego nie było i nie ma" ${ }^{10}$. Z tego powodu pamięć o nowych męczennikach w świadomości społecznej była znikoma, podobnie jak skryta i wyparta została pamięć o terrorze władzy bolszewickiej. Należy jednak podkreślić, że mimo iż wierni prawosławni w Związku Radzieckim oficjalnie nie otaczali kultem nowych męczenników, to bardzo ważna praca dokumentująca życie i śmierć męczenników była prowadzona od końca lat siedemdziesiątych przez Władimira Orłowskiego, który będąc studentem Instytutu Literackiego im. M. Gorkiego i osobą głęboko wierzącą, zainteresował się historią antyreligijnej polityki sowieckiej i zaczął zbierać materiały na ten temat. Złożyły się one później na siedmiotomowe wydanie Мyчeники, исповедники и подвижники благочестия Русской Православной Церкви ХX столетия (Męczennicy, wyznawcy i bohaterowie wiary Rosyjskiego Kościoła Prawostawnego XX stulecia, Moskwa 1992-2002). W roku 1988 Władimir Orłowski złożył śluby zakonne, otrzymując imię Damaskin; a obecnie jest ihumenem, członkiem Komisji Synodalnej do spraw Kanonizacji Nowych Męczenników i jednym $\mathrm{z}$ teoretyków nowego męczeństwa.

Komisja Synodalna została powołana do życia na jubileuszowym soborze w 1988 roku w ramach uroczystego świętowania tysiąclecia chrztu Rusi. Jej celem było gromadzenie materiałów do wyniesienia na ołtarze między innymi męczenników XX wieku. Dzięki temu już rok później, w roku 1989, kanonizowany został patriarcha Tichon (Biełławin) ${ }^{11}$, a upadek ZSRR umożliwił kolejne kanonizacje nowych męczenników.

${ }^{9}$ Прот. К. Каледа, Праздник Собора новомучеников и исповедников Российских, http://www. vladkan.ru/articles/pokrov01/p0000004.html [dostęp: 4.02.2017].

${ }^{10}$ Ответы митрополита Сергия (Страгородского) на пресс-конференции с представителями советской печати о положении православной церкви в СССР. 15 февраля 1930 г. [w:] Русская православная церковь..., s. 261.

${ }^{11}$ Rosyjski Kościół Prawosławny od 1700 roku był pozbawiony patriarchy, kierował nim Świątobliwy Synod Rządzący - kolegialna instytucja, w której skład wchodziło kilku najważniejszych hierarchów oraz reprezentujący władzę świecką oberprokurator. Poczynając od połowy XIX wieku, wśród 
25 marca 1991 roku Święty Synod Rosyjskiego Kościoła Prawosławnego wydał orzeczenie $O$ wznowieniu modlitewnego wspomnienia wyznawców i męczenników za Chrystusa, ustanowionego przez Sobór Lokalny z roku 1918, zaś w 1992 Sobór Biskupów ogłosił dzień 25 stycznia według kalendarza juliańskiego (lub najbliższą po nim niedzielę) świętem ku czci nowych męczenników i wyznawców rosyjskich oraz kanonizował siedem osób (między innymi metropolitów Włodzimierza (Bogojawlenskiego) i Beniamina (Kazanskiego), archimandrytę Sergiusza (Szeina), wielką księżnę Elżbietę Romanową). Powołano też wtedy komisje diecezjalne, które miały wspomóc Komisję Synodalną w procesie zbierania materiałów. Rola tych diecezjalnych komisji kanonizacyjnych polegała na gromadzeniu i analizie świadectw oraz dokumentów archiwalnych o nowych męczennikach, a następnie przekazaniu zweryfikowanych materiałów do Komisji Synodalnej, będącej „kluczowym agentem procesu kanonizacji”" 12 .

Kolejne kanonizacje nastąpiły w latach 1994 (2 osoby), 1997 (3 osoby), wreszcie na jubileuszowym soborze w roku 2000 na ołtarze wyniesiono 1097 osób, w tym członków rodziny carskiej. Jak czytamy na oficjalnej stronie Patriarchatu Moskiewskiego: „W historii świata nie było jeszcze takiej sytuacji, żeby kanonizowano tylu nowych niebiańskich orędowników"13. Jednocześnie - jak podkreśla badacz procesów kanonizacji w Kościołach prawosławnych Jarosław Charkiewicz-liczba świętych kanonizowanych w 2000 roku „kilkakrotnie przewyższa liczbę wszystkich wcześniej zaliczanych przez ten Kościół do grona świętych"'14, co wpływa na zmianę znaczenia męczeństwa dla Kościoła. W przygotowaniu kanonizacji nowych męczenników Patriarchat Moskiewski blisko współpracował z Rosyjskim Kościołem poza Granicami Rosji. Co prawda do oficjalnego połączenia obydwu Kościołów doszło dopiero w roku 2007, jednak - jak twierdzi Garrard - nie byłoby ono możliwe, gdyby nie krew nowych męczenników, która związała ze sobą te Kościoły ${ }^{15}$. W późniejszym okresie dokonano kolejnych kanonizacji, jednakże już na znacznie mniejszą skalę i z wyraźną tendencją spadkową (dla przykładu: rok 2002 - 147 osób, 2005 - 72 osoby, 2008 - 12 osób, 2010 - 2 osoby; ogółem w latach 2000-2010 kanonizowano 664 osoby, obecnie zaś trwają prace przede wszystkim nad uzgodnieniem list męczenników czczonych w Rosyjskim

prawosławnych hierarchów, duchowieństwa i świeckich pojawiały się głosy wzywające do głębokich reform Kościoła. Jednakże dopiero rewolucja lutowa i abdykacja cara Mikołaja II, przeciwnika jakichkolwiek zmian, umożliwiły zwołanie soboru, którego głównym zadaniem stało się uniezależnienie Kościoła od państwa. Najdobitniejszym tego wyrazem stał się wybór pierwszego od ponad 200 lat patriarchy - został nim Tichon (Biełławin), dotychczasowy metropolita moskiewski. Patriarsze Tichonowi przyszło rządzić w okresie niełatwym dla Kościoła. Był świadkiem prześladowań, konfiskaty dóbr kościelnych, represji wobec duchowieństwa. Sam od 1922 r. do swojej śmierci w 1925 przebywał w areszcie domowym w swojej celi w Dońskim monastyrze w Moskwie (Д.В. Поспеловский, Русская православная церковь в ХХ веке, Москва 1995, s. 19-40, 69-77).

${ }^{12}$ K.H. Christensen, The Making of the New Martyrs of Russia. Soviet Repression in Orthodox Memory. PhD dissertation, Copenhagen 2015, s. 75.

138 февраля - Собор новомучеников и исповедников Российских, http://www.patriarchia.ru/db/ text/194754.html [dostęp: 25.04.2015].

${ }^{14}$ J. Charkiewicz, Kanonizacja świętych w prawosławiu, Warszawa 2014, s. 92.

${ }_{15}$ J. Garrard, C. Garrard, Russian Orthodoxy Resurgent. Faith and Power in the New Russia, Princeton-Oxford 2008, s. 195. 
Kościele Prawosławnym i Rosyjskim Kościele Prawosławnym poza Granicami Rosji i nowe kanonizacje właściwie nie odbywają się $\left.{ }^{16}\right)$.

Zmniejszenie się liczby kanonizacji jest spowodowane różnymi czynnikami, w tym coraz bardziej ograniczonym dostępem do archiwów FSB, w których przechowywane są materiały dotyczące ofiar represji sowieckich, ale również zbyt powolnym w odczuciu Kościoła prawosławnego rozwojem kultu nowych męczenników. Jak powiedział w wywiadzie ihumen Damaskin (Orłowski):

[...] po prostu, mamy ich wystarczająco [...] czy jest jakiś sens w multiplikowaniu ludzkich imion w kalendarzu? Żeby poczuć tych ludzi jako żywych - i jeśli oni są święci, to powinni być tak postrzegani, ich doświadczenie, ludzie powinni się do nich zwracać, zauważać ich doświadczenie, próbować korzystać z ich doświadczenia... jakoś... i do tego już jest wystarczająco. To niemożliwe dla Kościoła powszechnego albo Rosyjskiego Kościoła Prawosławnego, żeby zaakceptować więcej niż tysiąc, półtora tysiąca świętych w XX wieku, to jest naprawdę dużo ${ }^{17}$.

Dlatego obecne prace Rosyjskiego Kościoła Prawosławnego koncentrują się na propagowaniu kultu nowych męczenników wśród wiernych.

W roku 2010 w ramach Komitetu Międzysoborowego powołano do życia Komisję do spraw Współpracy między Kościołem, Państwem i Społeczeństwem, której przedstawicielem został metropolita Juwenaliusz, wcześniej będący przewodniczącym Komisji do spraw Kanonizacji. W 2012 roku została powołana specjalna Rada Kościelno-Społeczna do spraw Upamiętniania Nowych Męczenników i Wyznawców Kościoła Rosyjskiego, która ma za zadanie realizację postanowień przyjętych w rozporządzeniu z 2011 roku zatytułowanym $O$ sposobach upamiętniania nowych męczenników, wyznawców $i$ wszystkich, którzy niewinnie ucierpieli z ręki bezbożników w latach prześladowañ ${ }^{18}$. Celem działań Rady było przygotowanie obchodów 100-lecia wybuchu rewolucji bolszewickiej w 2017 roku. Jak podkreślił jeden z mnichów Klasztoru Spotkania Włodzimierskiej Ikony Matki Bożej w Moskwie w trakcie wywiadu, który z nim przeprowadziłyśmy jeszcze w 2014 roku:

[...] zadanie polega na tym, aby w krótkim czasie, mniej więcej do roku 2017, zorganizować szereg imprez, tak by praca ta dotyczyła całego Kościoła, żeby we wszystkich diecezjach ludzie zaczęli na ten temat mówić. I nie tylko ludzie utożsamiający się z Kościołem, ale też świeccy, żeby rozumieli, czego doświadczył nasz $\mathrm{kraj}^{19}$ (o. Andriej).

Setna rocznica wybuchu rewolucji 1917 roku ma być zatem momentem intensywnego rozwoju kultu nowych męczenników, a co się z tym wiąże - zakorzenienia w społecznej świadomości prawosławnej wizji przeszłości. Ta interpretacja swój pierwszy całościowy kształt otrzymała w roku 2000, kiedy na uroczystą kanonizację nowych męczenników napisano i poświęcono ikonę Soboru Świętych Nowych Męczenników i Wyznawców Rosyjskich (il. 1).

16 Очерк по истории канонизации новомучеников и исповедников российских ХХ века, http:// sobor-voronezh.livejournal.com/104492.html [dostęp: 9.07.2016].

17 Wywiad z ihumenem Damaskinem (Orłowskim), 18 maja 2014 r.

18 Церковно-общественный совет при Патриархе Московском и всея Руси по увековечению памяти новомучеников и исповедников Церкви Русской, http://www.patriarchia.ru/db/text/2674769. html [dostęp: 25.03.2016].

19 Wywiad z o. Andriejem, przeprowadzony 30 października 2014 w Moskwie. 


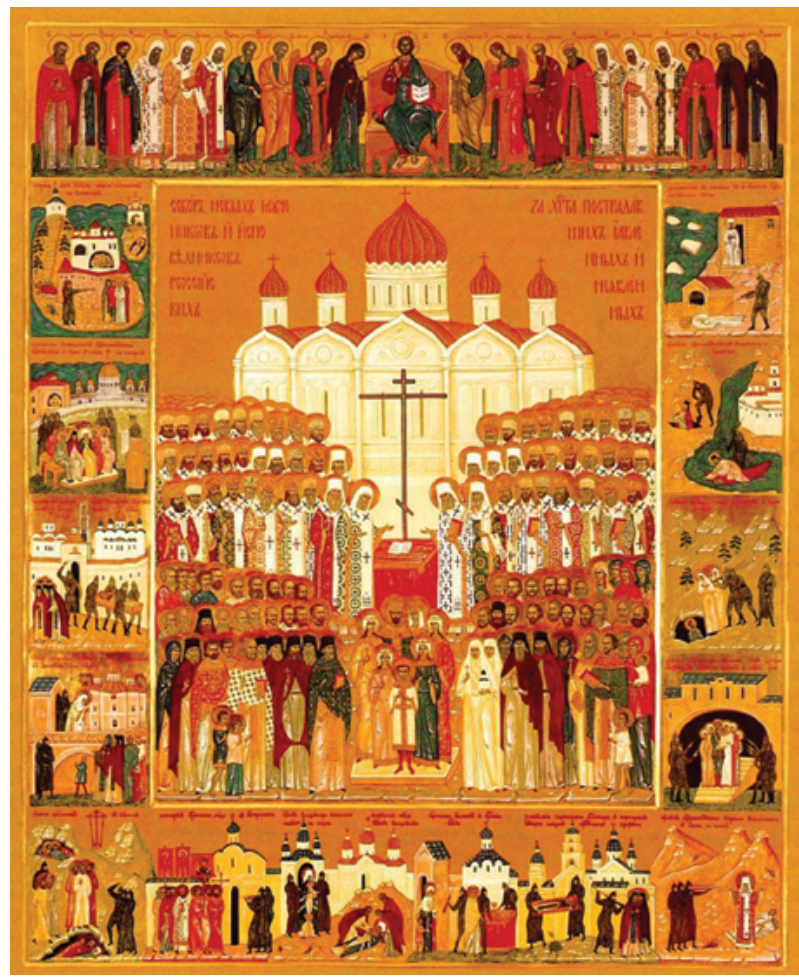

Il. 1. Ikona Soboru Świętych Nowych Męczenników i Wyznawców Rosyjskich. Reprodukcja ze strony: http://www.russned.ru/stats/2265 [dostęp: 10.10.2015]

\section{Ikona jako nośnik wiedzy o przeszłości}

W rosyjskim prawosławiu ikona ma nie tylko ważne znaczenie religijne, ale jest również nośnikiem wiedzy o przeszłości. Podstawową funkcją ikony - jak podkreślał Leonid Uspienski - jest zaświadczenie o Wcieleniu Chrystusa ${ }^{20}$, a także wyobrażenie człowieka przemienionego Bożą łaską, uczestniczącego w świętości Boga ${ }^{21}$. Podobnie Irina Jazykowa podkreśla ogromne znaczenie ikony w życiu prawosławnych wiernych ${ }^{22}$, dla których jest ona wezwaniem do świętości i wzorcem postępowania, zdolnym do przemienienia modlącej się przed nią osoby ${ }^{23}$. Jednocześnie badacze ikon zwracają uwagę na szczególną zdolność zawartych na klejmach epizodów do tworzenia jasnej i zwartej opowieści o przeszłości ${ }^{24}$. O dydaktycznym charakterze ikony pisze filozof zajmu-

${ }^{20}$ L. Uspienski, Teologia ikony, tłum. M. Żurowska, Poznań 1993, s. 8.

${ }^{21}$ Ibidem, s. 124-130.

${ }^{22}$ I. Jazykowa, Świat ikony, thum. ks. H. Paprocki, Warszawa 1998, s. 7-8.

23 Ibidem, s. 16; В.В. Бычков, Феномен иконы, Москва 2009, s. 198-199, 205.

${ }^{24}$ D. Lichaczow, Poetyka literatury staroruskiej, tłum. A. Prus-Bogusławski, Warszawa 1981, s. $24-31$. 
jący się historią estetyki bizantyjskiej, Wiktor Byczkow, odwołując się przy tym do postanowień VII Soboru Powszechnego w Nicei (787), w których podkreślono dwie podstawowe funkcje ikon - kommemoratywną (przypominanie wiernym o czczonych przez Kościół świętych) i anagogiczną (uwznioślenie, skierowanie myśli modlących się ku sprawom transcendentalnym). Uczestnicy soboru wskazali też, że kontemplacja ikony pozwala na duchowe współuczestnictwo w przedstawionej na niej scenie ${ }^{25}$.

Szczególną funkcję w procesie nauczania pełnią ikony hagiograficzne. Tego typu wyobrażenia zaczęły pojawiać się w Bizancjum na początku XII wieku, szczególnie popularne stały się zaś w świecie słowiańskim, gdzie - jak pisze Nancy Patterson Sevčenko - służyły upowszechnianiu kultu nowych świętych, takich jak Borys i Gleb czy Sergiusz z Radoneża, później zaś przedstawiały również sceny historyczne, pełniąc tym samym funkcję kroniki historycznej poszczególnych klasztorów czy Kościoła Rosyjskiego w jego powiązaniu z Wielkim Księstwem Moskiewskim² ${ }^{26}$. Warto podkreślić, że rola ikony w propagowaniu mitu założycielskiego wspólnoty i kształtowaniu tożsamości narodowej była typowa jedynie dla krajów słowiańskich. W Bizancjum akcent kładziono na kwestie etyczne - przedstawione na ikonach sceny z żywota świętego czy świętych miały być dla wiernych modelami zachowań, które pozwolą im osiągnąć Królestwo Niebieskie ${ }^{27}$.

Jak się wydaje, w przypadku analizowanej przez nas dalej ikony Soboru Nowych Męczenników i Wyznawców Rosyjskich mamy do czynienia z nawiązaniem do obydwu tradycji, choć na pierwszy plan zdecydowanie wysuwa się chęć stworzenia opowieści pełniącej funkcję mitu o odrodzeniu Kościoła prawosławnego po latach prześladowań. $Z$ tego właśnie względu w dalszej części artykułu przyjrzymy się bliżej przedstawieniu Soboru Nowych Męczenników i Wyznawców Rosyjskich, zwracając uwagę na dobór postaci, a zwłaszcza epizodów męczeńskich wyobrażonych na klejmach, oraz na sposób ich przedstawienia. Postaramy się określić, jakie sensy eksponuje, jakie fakty historyczne przedstawia jako kluczowe i jaką w ten sposób tworzy narrację o przeszłości. Jest to tym ważniejsze, że kult nowych męczenników nie jest w Rosji wynikiem naturalnej ewolucji, wypływającej z duchowych potrzeb wiernych, lecz w dużej mierze narzucony odgórnie przez hierarchię kościelną i - jak podkreśla o. Gieorgij Mitrofanow - świadomość znaczenia nowych męczenników jest niewielka wśród wiernych ${ }^{28}$. Dlatego nasze spojrzenie na ikonę ma nam pomóc zrozumieć odzwierciedloną w niej narrację o dwudziestowiecznych losach Rosyjskiego Kościoła Prawosławnego, co z kolei powinno prowadzić do wytłumaczenia, dlaczego Kościołowi tak bardzo zależy na rozwoju tego kultu.

25 В.В. Бычков, op.cit., s. 73

${ }^{26}$ N.P. Sevčenko, The Vita Icon and the Painter as a Hagiographer, „Dumbarton Oaks Paper” 1999, nr 53, s. 155-156.

27 Ibidem, s. 151.

28 Г. Мирофанов, Почитание новомучеников в нашей иееркви так и не сложилось, http://psmb.ru/ newmartyrs/article/protoierei-georgii-mitrofanov-pochitanie-novomucheni-6281/ [dostęp: 11.05.2016]. Por. Z. Bogumil, The Solovetski Islands and Butovo as two „Russian Golgothas”. New Martyrdom as a Means to Understand Russian Repression [w:] (Hi-)Stories of the Gulag. Fiction and Reality, F. Fischer von Weikersthal, K. Thaidigsmann (red.), Heidelberg 2016, s. 133-154. 


\section{Historia prześladowań Kościoła zapisana na ikonie}

Ikonę namalowała znana ikonopisarka Maria Glebowa z Prawosławnego Uniwersytetu Teologicznego im. św. Tichona. Ikona ma wymiary 167 x $135 \mathrm{~cm}$ i łączy w sobie typ ikony soboru świętych z ikoną hagiograficzną, zawierającą wokół centralnego wyobrażenia najważniejsze sceny (tak zwana klejma) z żywotów przedstawionych postaci, mające najpełniej oddawać istotę ich drogi duchowej i męczeńskiej śmierci.

$\mathrm{Na}$ środkowej części ikony (średniku) wyobrażono rzesze świętych zgromadzonych wokół rodziny carskiej i kilkunastu najbardziej rozpoznawalnych męczenników reprezentujących poszczególne grupy wiernych: hierarchów, duchownych, mnichów i świeckich. Znajdują się oni na tle świątyni mającej postać cerkwi Chrystusa Zbawiciela w Moskwie, nad nimi zaś umieszczono rząd deesis, czyli tradycyjne przedstawienie Chrystusa na tronie, po którego prawej i lewej stronie stoją w postawie modlitewnej Bogurodzica i Jan Chrzciciel, w danym wypadku wraz z archaniołami, apostołami Piotrem i Pawłem oraz najważniejszymi rosyjskimi świętymi z wieków $\mathrm{X}$-XIX. Ma to podkreślić ciągłość historii i organiczny związek między męczennikami XX wieku i Kościołem rosyjskim wcześniejszych stuleci ${ }^{29}$, zaś umieszczenie pośrodku carskiej rodziny ma wyeksponować znaczenie władzy świeckiej oraz idei „prawosławnego cara”. Jak można przeczytać w oficjalnym opisie ikony przygotowanym przez Prawosławny Uniwersytet Teologiczny im. św. Tichona, „Rodzina Carska przedstawiona jest $\mathrm{w}$ bizantyjskich strojach cesarskich [...] podkreślających nierozerwalny związek między Bizancjum i Rosją" ${ }^{30}$. W tym stwierdzeniu można widzieć zarówno bezpośrednie odwołanie do historii Rusi, która utrzymywała bliskie i na ogół poprawne kontakty z Konstantynopolem, umacniane poprzez małżeństwa dynastyczne, jak i nawiązanie do wspólnoty wyznaniowej i kulturowej, czy wreszcie do koncepcji Moskwy - Trzeciego Rzymu, zgodnie z którą po upadku Bizancjum to Państwo Moskiewskie miało stać się duchowym centrum prawosławia.

Jak powiedział o. Aleksandr Sałtykow, dziekan Wydziału Sztuk Pięknych Prawosławnego Uniwersytetu Teologicznego im. Świętego Tichona i jeden z twórców ikony, średnik i rząd deesis zostały napisane zgodnie z tradycyjnymi wzorcami, klejma natomiast są całkowicie nowymi kompozycjami, do tego umieszczonymi nie w kolejności chronologicznej, jak to zwykle bywa na ikonach hagiograficznych, lecz geograficznie: u góry wyobrażono wydarzenia zaistniałe na północy, u dołu te, które nastąpiły na południu Rosji ${ }^{31}$. Piętnaście klejm przedstawia zarówno sceny męczeństwa konkretnych postaci, jak i obrazy zbiorowe, które w zamyśle twórców ikony miały najpełniej charakteryzować świadectwo wiary Kościoła Rosyjskiego XX wieku. To te wydarzenia zostały wybrane i wokół nich, jako kluczowych według Kościoła momentów represji, budowana jest opowieść o prześladowaniach nowych męczenników.

${ }^{29}$ Więcej na temat symboliki tej części ikony zob. Описание иконы собора святых новомучеников и исповедников российских, http://www.pravmir.ru/opisanie-ikony-sobora-svyatyx-novomuchenikov-iispovednikov-rossijskix/ [dostęp: 11.05.2016].

${ }^{30}$ Ibidem; por. Z. Bogumił, Pamięć Gułagu, Kraków 2012, s. 131-135.

${ }^{31}$ Ibidem. 
Od samego początku rewolucji władze sowieckie rozpoczęły agresywną kampanię przeciwko duchowieństwu. 31 października 1917 roku oddziały bolszewików zajęły miejscowość Carskoje Sieło w pobliżu Petersburga, aresztowały miejscowe duchowieństwo i rozstrzelały próbującego wyjaśnić zaistniałą sytuację ks. Ioanna Koczurowa. 25 stycznia 1918 roku został zastrzelony pierwszy hierarcha, Włodzimierz (Bogojawlenski), metropolita kijowski i halicki, honorowy przewodniczący wciąż trwającego soboru lokalnego. Aresztowano go we własnej rezydencji w Ławrze Kijowsko-Peczerskiej, wyprowadzono poza mury klasztoru i tam rozstrzelano.

Warto zwrócić uwagę, że zabójstwo o. Koczurowa nie zostało przedstawione na żadnym z klejm ikony Soboru Nowych Męczenników i Wyznawców Rosyjskich, mimo że swego czasu odbiło się ono szerokim echem wśród wiernych diecezji piotrogrodzkiej oraz uczestników Soboru Lokalnego i już wtedy, w listopadzie 1917 roku, zostało nazwane męczeństwem ${ }^{32}$. Duchowny był zresztą kanonizowany w roku 1994 i przedstawiony na średniku ikony nowych męczenników w pierwszym rzędzie z lewej strony od rodziny carskiej. Pierwsze klejmo ikony twórcy poświęcili natomiast zabójstwu pierwszego hierarchy, co pokazuje, że dyskurs nowego męczeństwa to przede wszystkim pamięć o hierarchach kościelnych. Warto jednak podkreślić, że to przypisywanie wyjątkowego znaczenia męczeństwu hierarchów ma swoje historyczne korzenie. Zabójstwo metropolity w 1918 roku było dla Kościoła ogromnym wstrząsem, o czym świadczy fakt, że data jego śmierci już po kilku miesiącach stała się dniem wspomnienia wszystkich zmarłych za wiarę w prześladowaniach ze strony bolszewików (od 1992 roku to data święta Nowych Męczenników i Wyznawców Rosyjskich w Rosji, Kościół poza Granicami Rosji świętuje ją od roku 1981). W opisie przedstawiającego to wydarzenie jedenastego klejma czytamy:

Sama chwila zabójstwa nie jest tu przedstawiona, gdyż takich scen i tak jest już wystarczająco dużo na ikonie. Metropolita jest pokazany dwa razy: w chwili wyprowadzania na rozstrzelanie i w chwili odnalezienia jego ciała przez mnichów. Jego rozpostarte ciało kompozycyjnie znajduje się prawie w centrum całego rzędu i jest praktycznie w tym samym pionie, co środkowe postaci deesis i średnika, czyli finalizuje linię pionową łączącą Zbawiciela - kopułę cerkwi krzyż - ołtarz - carskich męczenników - kapłana męczennika Włodzimierza. Podkreśla to znaczenie męczeństwa tego wybitnego hierarchy [...] Przez swój akt wiary metropolita upodobnił się do Chrystusa, co jest w sposób artystyczny przestawione na ikonie ${ }^{33}$.

Jak widać, odpowiednie przedstawienie i umiejscowienie klejma wyobrażającego męczeństwo metropolity Włodzimierza pozwala nadać mu odpowiednią rangę i podkreślić fundamentalne znaczenie tego wydarzenia dla dyskursu nowego męczeństwa.

Do końca 1917 roku, według bazy danych opracowywanej przez naukowców z Prawosławnego Uniwersytetu Teologicznego im. św. Tichona ${ }^{34}$, męczeńską śmierć

\footnotetext{
${ }^{32}$ Священномученик Иоанн Кочуров, http://days.pravoslavie.ru/Life/life363.htm [dostęp: 11.05. 2016].

${ }_{33}$ Икона собора новомучеников и исповедников российских, http://hram-poligon-kommunarka. ru/content/view/14/13/ [dostęp: 20.11.2015].

${ }^{34}$ Новумученики, исповедники, за Христа пострадавщие в годы гонений на Русскую Православную Церковь в XX в., http://213.171.53.29/bin/code.exe/frames/m/ind_oem.html/charset/
} 
poniosło co najmniej 16 osób. 31 marca 1918 roku, kiedy liczba znanych Synodowi z imienia i nazwiska zamordowanych duchownych osiągnęła 15, w cerkwi Moskiewskiej Akademii Duchownej pod przewodnictwem patriarchy Tichona została odprawiona pierwsza liturgia za spokój dusz „nowych męczenników”, „zamordowanych za wiarę i Kościół Prawosławny"35. Natomiast 5 kwietnia tegoż roku Święty Sobór Rosyjskiego Kościoła Prawosławnego wydał orzeczenie $O$ posunięciach spowodowanych prześladowaniami Kościoła Prawosławnego, wprowadzające specjalne modlitwy w cerkwi za osoby prześladowane za wiarę oraz za zmarłych „wyznawców i męczenników". To wówczas ustanowiono dzień zabójstwa metropolity Włodzimierza, 25 stycznia (lub najbliższą po tym dniu niedzielę), dorocznym dniem wspomnienia ,wszystkich zmarłych w obecnych straszliwych czasach prześladowań wyznawców i męczenników"36.

Pomimo tych prześladowań Rosyjski Kościół Prawosławny starał się zachować stanowisko neutralne i nie opowiadać się za żadnym z istniejących ugrupowań politycznych. Już 1 września 1917 roku w związku z groźbą wybuchu wojny domowej Sobór podjął uchwałę, w której podkreślono, że „wierna świętym zasadom Cerkiew Rosyjska nie bierze udziału w walce partii politycznych" ${ }^{37}$. Również kolejne apele kierowane do wszystkich uczestników konfliktów zbrojnych zawierały wezwania do przebaczenia, miłosierdzia i zaprzestania przelewu krwi. Nawet w znamienitej anatemie patriarchy Tichona z 19 stycznia 1918 roku - jak podkreśla Dmitrij Pospiełowski - ani raz nie są wspomniani bolszewicy lub władza radziecka; ekskomunice podlegają wszyscy zabójcy i mordercy terroryzujący ludność, niezależnie od ich przekonań politycznych $^{38}$. A w posłaniu z 6 (21) lipca 1918 roku patriarcha Tichon przestrzega wiernych przed chęcią zemsty i użyciem przemocy w odpowiedzi na przemoc ze strony państwa. Warto podkreślić, że to niedookreślenie, kto był winny represji, jest widoczne do dzisiaj w cerkiewnej interpretacji przeszłości, która zdecydowanie akcentuje zwycięstwo nowych męczenników i Chrystusa nad złem ${ }^{39}$.

Taka interpretacja ma ogromny wpływ na sposób przedstawienia sprawców na ikonie. Podczas gdy nowych męczenników wyobrażono na niej w kolorowych szatach, oprawcy zostali przedstawieni jedynie w zarysie i w kolorystyce błotnistoziemistej. Jak podkreślała w wywiadzie Maria Niecwietajewa, historyk sztuki, pracownik Katedry Historii i Teorii Sztuki Chrześcijańskiej Prawosławnego Uniwersytetu Teologicznego im. św. Tichona, tak liczna obecność oprawców na ikonie i fakt, że

oem/ans [dostęp: 9.07.2016]. Wspomniana baza danych jest pierwszą tego typu bazą komputerową, najpełniejszą i na bieżąco aktualizowaną.

${ }_{35}$ Кочуров Иван Александрович, http://kuz1.pstbi.ccas.ru/bin/nkws.exe/no_dbpath/docum/ans/ nm?HYZ9EJxGHoxITcGZeu-yPq6o9X6r [dostęp: 9.07.2016].

${ }_{36}$ Русская православная иерковь и коммунистическое..., s. 18. Tłumaczenie moje - M.Ł.

${ }^{37}$ Cyt. za: M. Maszkiewicz, Mistyka i rewolucja. Aleksander Wwiedeński i jego koncepcja roli cerkwi w państwie komunistycznym, Kraków 1995, s. 35.

38 Д.В. Поспеловский, op.cit., s. 52.

39 Zob. na przykład 3.П. Иноземцева, Подвиг веры русского народа в ХХ столетии и его отражение в житиях новомучеников и исповедников российских, http://www.fond.ru/index.php? menu_id $=375 \&$ menu_parent_id $=0 \&$ show_date $=1 \&$ category_id $=15 \&$ article_page_content $=0 \&$ show_preview_img $=0 \&$ show_file_list $=1 \&$ flag $=$ ajax\&page $=1 \&$ regime $=$ site\&content_id $=17 \overline{6}$ [dostęp: 9.07.2016]. 
przypominają wyglądem żołnierzy, były celowe, chodziło bowiem o zachowanie „prawdy historycznej” ${ }^{40}$. W ten sposób ikona, według Niecwietajewej, ma podkreślać realia historyczne. Jednak - jak zauważa brytyjska badaczka pamięci o nowych męczennikach Julie Fedor ${ }^{41}$ - wyobrażone na ikonie czapki czerwonoarmistów (budionowki), stanowiące ich atrybut, silnie nawiązują do szpiczastych hełmów żołnierzy rzymskich, którzy w pierwszych wiekach prześladowali chrześcijan. W rezultacie, podczas gdy nowi męczennicy są przedstawieni z zachowaniem indywidualności każdego z nich, obraz oprawców jest mocno schematyczny i uogólniony, są oni pozbawieni cech indywidualnych, a nawet ludzkich. Jak tłumaczono na łamach moskiewskiej gazety codziennej „Argumenty i Fakty”: „Figury czerwonoarmistów są specjalnie niedopracowane graficznie, przez co podkreślono, że żołnierze są tylko bezwolnym narzędziem w rękach biesów, które wojują z Kościołem" ${ }^{42}$. Czerwonoarmiści nie są zatem postaciami historycznymi, ale symbolicznym narzędziem szatana.

W roku 1918 prześladowania Kościoła przez władze komunistyczne przybrały na sile. W związku z rozszerzaniem się zasięgu wojny domowej i wprowadzeniem „czerwonego terroru” latem 1918 roku zaczęły się masowe aresztowania i rozstrzelania duchowieństwa, traktowanego jak ,wróg rewolucji”. Według przybliżonych obliczeń Dmitrija Pospiełowskiego, w latach 1918-1920 zostało zamordowanych co najmniej 28 biskupów, kilka tysięcy duchownych i mnichów oraz 12 tysięcy świeckich zaangażowanych w działalność Kościoła ${ }^{43}$. Niektóre wydarzenia tych lat uwieczniono na ikonie nowych męczenników jako szczególnie ważne.

Oprócz wspomnianego już zabójstwa metropolity Włodzimierza (Bogojawlenskiego), za jeden z kluczowych epizodów męczeństwa uznano bestialskie zamordowanie w czerwcu 1918 roku dwóch innych hierarchów: zakopanego żywcem arcybiskupa Permskiego i Solikamskiego Andronika (Nikolskiego) oraz utopionego w rzece biskupa Tobolskiego i Syberyjskiego Hermogena (Dołganiowa). Obaj hierarchowie cieszyli się ogromnym szacunkiem wśród wiernych, obydwa okrutne zabójstwa zostały dokonane prawie jednocześnie, w odstępie kilku dni: biskup Hermogen zginął 16 czerwca, zaś arcybiskup Andronik 20 czerwca 1918 roku. Z tego względu zostali wspólnie umieszczeni na czwartym klejmie ikony. Bardzo znacząca jest kompozycja ich przedstawienia.

Ogromnego znaczenia symbolicznego nabiera tu miasto na brzegu za rzeką, które w sensie dosłownym przedstawia Tobolsk. [...] promieniejąca biel murów i złoto kopuł w kontekście żywiołów, przemienionych poprzez męczeństwo świętych, nadają całemu obrazowi zaskakująco świąteczny charakter. Miasto staje się symbolem niebiańskiego Jeruzalem. Rzeka, którą można tu najwyraźniej symbolicznie potraktować jako rzekę utrapień, oddziela je od ziemi pełnej cierpień. W ten sposób różne płaszczyzny bytu łączą się na ikonie w jedną całość, świadcząc

40 Чьи чувства оскорбляют красноармейцьь на иконах новомучеников?, http://www.taday.ru/ text/1989298.html [dostęp: 12.03.2016].

${ }^{41}$ J. Fedor, Setting the Soviet Past in Stone: The Iconography of the New Martyrs of the Russian Orthodox Church, ,Australian Slavonic and East European Studies” 2014, vol. 28, nr 1-2, s. 121-153.

42 Икона новых святыхмучеников в храме Христа Спасителя, http://www.aif.ru/archive/1710912 [dostęp: 5.07.2016].

43 Д.В. Поспеловский, op.cit., s. 166-167. 
przede wszystkim o życiu wiecznym w Królestwie Niebieskim, które osiąga się przechodząc przez ciasną bramę cierpień i ucisków ${ }^{44}$.

Klejmo wyraża też wyjąatkowe okrucieństwo władzy radzieckiej wobec wierzących.

Kolejnym znaczącym wydarzeniem tego okresu represji było zabójstwo cara Mikołaja II wraz z żoną i pięciorgiem dzieci oraz służącymi 17 lipca 1918 roku w piwnicy domu Ipatiewa w Jekaterynburgu. Służący, kanonizowani w roku 1981 przez Rosyjski Kościół Prawosławny poza Granicami Rosji wraz z rodziną carską, nie zostali wyniesieni na ołtarze podczas kanonizacji nowych męczenników przeprowadzonej w Rosyjskim Kościele Prawosławnym w roku 2000, dopiero w styczniu 2016 roku kanonizowano lekarza rodziny carskiej ${ }^{45}$. Ponieważ ikona została napisana w roku 2000, ósme klejmo przedstawia jedynie rodzinę carską i jej zabójców. Symbolika tego przedstawienia jest bardzo wymowna i oparta na faktach historycznych:

Piwnica jest przedstawiona jako pomieszczenie o sklepionym stropie, nad którym umownie wyobrażono dom, co wskazuje miejsce tego wydarzenia. Carscy męczennicy są pokazani na schodach, po których byli prowadzeni. Schody te stają się piedestałem, na którym pokornie i majestatycznie stoją carscy męczennicy. Po stopniach schodów, które stały się dla nich drabiną Jakubową, wstępują oni do nieba. Zabójcy, przedstawieni z dwóch stron w brzydkich, nienaturalnych pozach, strzelają do świętych. Męczennicy przedstawieni są jako stojący blisko siebie, co wyraża właściwą im głęboką jedność. Pośrodku wznosi się surowa, zdecydowana postać Cara z synem Carewiczem Aleksym na ręku ${ }^{46}$.

Scena została umieszczona na tej samej wysokości co klejmo przedstawiające patriarchę Tichona, znajdujące się po drugiej stronie średnika, gdyż

[...] są to dwa zasadnicze tematy, umieszczone w kompozycji u podstaw średnika. W pionie kompozycja z carskimi męczennikami jest znaczeniowo połączona z dwoma znajdującymi się wyżej klejmami, przedstawiającymi męczennicę Elżbietę oraz miasto Tobolsk ${ }^{47}$.

Zabójstwo dalszej rodziny cara, w tym mniszki Elżbiety Romanowej, wielkiego księcia Sergiusza (Michajłowicza), książąt Jana, Konstantego, Igora i Władimira oraz towarzyszącej Elżbiecie mniszki Barbary, którego dokonano 18 lipca 1918 roku w Ałapajewsku, jest kolejnym znaczącym wydarzeniem represji w dyskursie nowego męczeństwa. Wszystkie te osoby zostały wrzucone do pustego szybu starej kopalni, gdzie zmarły na skutek ran. O momencie śmierci Elżbiety Romanowej opowiada szóste klejmo ikony.

Ostatnimi słowami wypowiedzianymi przez męczennicę Elżbietę były słowa Zbawiciela: „Boże, przebacz im, gdyż nie wiedzą, co czynią”. Duch tych świętych słów znajduje swoje odbicie w klejmie: jest tu mało ruchu, za to dużo spokojnej przestrzeni, która oznacza pustkowie

44 Икона собора новомучеников...

45 Определение Освящзенного Архиерейского Собора Русской Православной Церкви об общеиерковном прославлении ряда местночтимых святых, http://www.patriarchia.ru/db/text/4367765. html [dostęp: 20.02.2016].

46 Икона собора новомучеников...

47 Ibidem. 
(gdyż zabójstwa dokonano w oddali od miasta); nawet wrogie działania łotrów, przedstawionych w błotnistozielonych strojach, nie mogą zakłócić wyrażonego w kompozycji spokojnego nastroju ${ }^{48}$.

Elżbieta Romanowa jest jednym z cieszących się największą czcią nowych męczenników nie tylko z powodu swej śmierci, lecz także ze względu na postawę życiową i działalność przed rewolucją bolszewicką. Kiedy jej mąż, wielki książę Sergiusz (Aleksandrowicz), zginął w wyniku zamachu w trakcie rewolucji 1905 roku, Elżbieta złożyła śluby monastyczne i założyła w Moskwie klasztor żeński pod wezwaniem św. Marty i Marii, powołany do działalności charytatywnej wśród najuboższych. Na ikonie jest ona przedstawiona na szóstym klejmie wraz z mniszką Barbarą; obydwie były kanonizowane przez Rosyjski Kościół Prawosławny w 1992 roku, pozostali członkowie dalszej rodziny cara byli wyniesieni na ołtarze jedynie przez Rosyjski Kościół Prawosławny poza Granicami Rosji w 1981 roku. Co ciekawe jednak, na analizowanym klejmie wszystkie ofiary (czyli mniszki Elżbieta i Barbara oraz znajdujący się już w szybie kopalnianym mężczyzna, zapewne jeden z książąt) mają wokół głów nimby.

Oprócz tych męczeńskich śmierci konkretnych świętych, na ikonie przedstawiono również sceny będące uogólnieniem prześladowań wierzących w pierwszych latach władzy radzieckiej. To rozstrzelanie procesji w Astrachaniu (klejmo 10) oraz rozgrabienie Ławry Troicko-Siergijewskiej i zbezczeszczenie relikwii św. Sergiusza z Radoneża (klejmo 5). W tych przypadkach mamy do czynienia z konkretnymi wydarzeniami wybranymi spośród wielu podobnych faktów. Procesję w Astrachaniu rozstrzelano na rozkaz Kirowa 24 maja 1919 roku, analogiczne wypadki zdarzyły się między innymi w Tule i Charkowie (5 lutego 1918 roku), Woroneżu (8 lutego 1918 roku) czy też wsi Bolszoj Azias w Mordowii (1 marca 1919 roku). Jak można przeczytać $\mathrm{w}$ interpretacji ikony:

[...] procesje będące znakiem protestu wobec prześladowań Kościoła były organizowane w wielu miastach w latach 1918-1919. Odpowiedzią na ten przejaw ludowego protestu był terror. [...] Kompozycja wyraża bezpośrednią konfrontację dwóch si149.

Przedstawiony wśród uczestników procesji arcybiskup Mitrofan (Krasnopolski) poprzez rangę swojego stanu duchownego symbolizuje siłę zderzenia dobra ze złem i podkreśla przekaz, dlatego został wyobrażony na ikonie, mimo iż w rzeczywistości zginął dopiero kilkadziesiąt dni później, aresztowany i rozstrzelany przez miejscowych czekistów. Warto podkreślić, że kompozycja tego klejma nawiązuje do przedstawienia oblężenia Nowogrodu przez wojska Suzdalu na ikonie Matki Bożej „Znak” z pierwszej połowy XVI wieku, jednak, jak można przeczytać w opisie, „została stworzona w pełni samodzielna kompozycja. Dzięki dramatyzmowi zawartemu w konfrontacji dwóch niezłomnych sił klejmo wyróżnia się na tle pozostałych scen" ${ }^{50}$. Czerpie zatem siłę swojego oddziaływania także z rangi widoku, do którego nawiązuje.
48 Ibidem.
49 Ibidem.
50 Ibidem. 
Z kolei kompozycja przedstawiająca Ławrę Troicko-Siergijewską wyobraża wydarzenia z lat 1919-1920, kiedy to zgodnie z rozporządzeniem Ludowego Komisariatu Sprawiedliwości rozpoczęła się tak zwana akcja otwarcia relikwii, mająca na celu „walkę z zabobonami” przez udowodnienie, że czczone przez wiernych szczątki świętych nie mają żadnych szczególnych właściwości i ulegają rozkładowi, a Kościół jedynie mamił ludzi, twierdząc, że posiadają cudowną moc. Były one publicznie badane przez specjalną komisję, a następnie na ogół zabierane do muzeów ${ }^{51}$. W ciągu dwóch lat poddano takim badaniom ciała 97 świętych na terenie całej Rosji, szczególne wrażenie zrobiło właśnie otwarcie relikwiarza wyjątkowo czczonego św. Sergiusza z Radoneża. W celach propagandowych cały proces został nawet sfilmowany przez bolszewików. Jak pisze bowiem Robert Green, władza bolszewicka traktowała kino jako jedno z najważniejszych i najskuteczniejszych narzędzi walki ze świętymi, dlatego w ciągu czterech miesięcy 1919 roku wydała ogromne jak na ówczesne warunki środki na reprodukcje slajdów, zdjęć i filmów pokazujących ekshumację Tichona Zadońskiego, Sergiusza z Radoneża i księcia Michała Twerskiego $^{52}$. Dla podkreślenia doniosłości walki, jaką bolszewicy wytoczyli relikwiom świętym, i przede wszystkim znaczenia kultu relikwii dla prawosławia, historia ta została przedstawiona na ikonie w sposób bardzo wzniosły. Jak czytamy w opisie, „ta scena, najbardziej świetlista wśród klejm lewego rzędu, jest jego ośrodkiem i dlatego niesie najwięcej znaczeń" 53 . Podobnego typu wydarzenie - zniszczenie klasztoru w Sarowie i kradzież relikwii św. Serafina - przedstawione jest na klejmie 14, jednak to już epizod z lat późniejszych (1925-1927).

Klejma 12 i 13 (w niektórych opisach traktowane jako jedno klejmo 12) również przedstawiają sceny będące uogólnieniem prześladowań wierzących w pierwszych latach władzy radzieckiej, nie są to jednak żadne konkretne wydarzenia, lecz wyobrażenia o charakterze wręcz symbolicznym, zwracające uwagę na znaczenie cierpienia duchowieństwa parafialnego i zwykłych ludzi. Tak więc klejmo 13 - przedstawiające aresztowanego kapłana i żołnierza sięgającego po stojący na ołtarzu kielich (naczynie liturgiczne służące do sprawowania Eucharystii) - nawiązuje do częstych, zwłaszcza w pierwszych latach po rewolucji, przypadków zatrzymań i egzekucji duchowieństwa bezpośrednio w cerkwi, nierzadko wręcz podczas odprawiania nabożeństw. Jak czytamy w interpretacji ikony:

Znane są liczne przypadki [...] kiedy prześladowcy wpadali prosto do ołtarza w momencie odprawiania nabożeństwa, bezcześcili utensylia liturgiczne, aresztowali lub mordowali duchownych. Na ikonie mamy uogólnione przedstawienie takiego aktu przemocy. Ukazano tu niewielką cerkiew z jedną kopułą i białymi murami, taką, jakich w całej Rosji było ogromne mnóstwo. [...] Kompozycja jest ściśle związana z poprzednim przedstawieniem świętej żony z dziećmi

${ }^{51}$ K. Pawełczyk-Dura, Kampania otwierania świętych relikwii jako element antycerkiewnej polityki władz komunistycznych, „Studia Religiologica” 2012, nr 3 (45), s. 231-233.

${ }_{52}$ R.H. Greene, Bodies Like Bright Stars: Saints and Relics in Orthodox Russia, DeKalb 2010, s. $153-154$.

53 Икона собора новомучеников... 
(łączy je zielona ziemia, na której stoją), gdyż obie sceny są poświęcone życiu zwykłej parafii, którą dotknęły represje $\mathrm{e}^{54}$.

Jednocześnie wspomniane przedstawienie może, zdaniem o. Aleksandra Sałtykowa, stanowić bardziej konkretne nawiązanie do kolejnej fali prześladowań z lat 1921-1923. Ogłoszony 27 grudnia 1921 roku Dekret o konfiskacie kosztowności (jako pretekst posłużyła klęska głodu, która ogarnęła wówczas Rosję, a zwłaszcza Powołże) pociągnął za sobą represje wobec wiernych stawiających rzeczywisty lub rzekomy opór podczas prób odebrania należących do cerkwi przedmiotów wartościowych (w tym utensyliów liturgicznych). Jak czytamy w interpretacji ikony:

Kościół prawosławny sam zaproponował, że odda swe kosztowności na pomoc głodującym, z wyjątkiem utensyliów liturgicznych. Zostało to wykorzystane jako pretekst do prześladowań i brutalnego, z założenia świętokradczego odebrania naczyń używanych do sprawowania Eucharystii. Użyta gama kolorystyczna akcentuje czerwony materiał znajdujący się na ołtarzu, co wiąże dane wydarzenie z przedstawieniem ołtarza na środkowej części ikony i kładzie nacisk na duchowe zwycięstwo prześladowanych nad ich gnębicielami ${ }^{55}$.

Z kolei pokazana na klejmie 12 bezimienna kobieta symbolizuje cierpienie, jakiego doznawały żony duchownych z dziećmi po aresztowaniu męża i ojca. Podkreśla ona jednocześnie znaczenie roli, jaką odegrały w latach prześladowań Kościoła żony aresztowanych i rozstrzelanych kapłanów, czy szerzej - wierzące kobiety. Pozostając na wolności, dbały o świątynie, wychowywały pozbawione ojca dzieci, przekazywały paczki do więzienia czy też dobrowolnie towarzyszyły duchownym na zesłaniu. Patriarcha Tichon nazywał je „białymi chusteczkami” (od noszonych na głowie chustek) i podkreślał ich znaczenie dla Kościoła. Warto podkreślić, że do dzisiaj istnieje przekonanie, że to właśnie dzięki prostym „,babulkom” udało się przetrwać lata prześladowań ${ }^{56}$.

Ogółem w latach 1921-1923 represjonowanych było około 10 tysięcy osób, z czego kilka tysięcy rozstrzelano ${ }^{57}$. Charakterystyczną cechą tej fali prześladowań była, jak podkreśla o. Gieorgij Mitrofanow, organizacja pokazowych procesów duchowieństwa, oskarżanego o odmowę wydania kosztowności cerkiewnych i okazania w ten sposób pomocy głodującym ${ }^{58}$. Do najbardziej znanych tego typu procesów należał sąd nad metropolitą piotrogrodzkim i gdowskim Beniaminem (Kazańskim) i grupą wiernych, pokazany na trzecim klejmie ikony nowych męczenników i wyznawców. Zostali oni skazani na śmierć i rozstrzelani w sierpniu 1922 roku; na

${ }^{54}$ Ibidem.

${ }^{55}$ Ibidem.

${ }_{56}$ Zob. na przykład Е. Жосул, Не ищите женщину, http://www.pravmir.ru/ne-ishhite-zhenshhinu/ [dostęp: 9.07.2016].

57 A. Kaszewarow szacuje liczbę ofiar na 2 tysiące (А.Н. Кашеваров, Православная российская церковь и советское государство (1917-1922), Москва 2005, s. 239), natomiast prot. Gieorgij Mitrofanow mówi o 6-7 tysiącach (прот. Г. Митрофанов, Канонизация новомучеников и исповедников российских в Русской Православной Церкви, http://www.pravmir.ru/protoierej-georgijmitrofanov-kanonizaciya-novomuchenikov-i-ispovednikov-rossijskix-v-russkoj-pravoslavnoj-cerkvi/ [dostęp: 9.07.2016].

${ }^{58}$ Г. Митрофанов, Канонизация новомучеников... 
ikonie przedstawieni są podczas toczącego się ich procesu, zaś detale tła (sobór św. Izaaka oraz wybudowane jeszcze w XIX wieku więzienie Kresty, w którym za czasów radzieckich przetrzymywano głównie więźniów politycznych) wskazują na miejsce wydarzenia - Petersburg (wówczas nazywany Piotrogrodem). Z kolei użyta kolorystyka ubrań podkreśla przekaz zbudowany na zasadzie kontrastu, „oskarżeni przedstawieni są w barwnych, jasnych strojach, które symbolizują ich niewinność i świętość" 59 .

Inne ważne wydarzenie $\mathrm{z}$ tych samych lat przedstawia klejmo siódme. Jest nim uwięzienie patriarchy Tichona w Klasztorze Dońskim, gdzie przebywał on w latach 1922-1925. Areszt domowy został tu potraktowany jako kwintesencja jego posługi jako patriarchy, na którego barkach do połowy lat dwudziestych spoczywały losy Rosyjskiego Kościoła Prawosławnego. Patriarcha Tichon zmarł śmiercią naturalną (na skutek niewydolności krążenia) w szpitalu 7 kwietnia 1925 roku, jednakże już w roku 1989 został kanonizowany jako święty biskup i wyznawca (tym mianem określano świętych, którzy byli prześladowani i złożyli świadectwo wiary chrześcijańskiej, jednak nie zmarli śmiercią męczeńską) ze względu na znaczenie jego posługi dla Kościoła rosyjskiego.

Patriarcha Tichon był szykanowany przez władzę radziecką od września 1918 roku: oskarżano go o współpracę z zagranicą i działalność kontrrewolucyjną, wytoczono sprawy karne, zakazano opuszczania Moskwy, dwa razy osadzono w areszcie domowym. Mimo zamknięcia, cały czas cieszył się wśród wiernych ogromnym autorytetem, co przedstawia poświęcone mu klejmo ikony, na której jest on wyobrażony jako udzielający błogosławieństwa ludziom zgromadzonym przy murach służącego za więzienie klasztoru. Jak czytamy w opisie, w klejmie

[...] znalazła odzwierciedlenie konkretna rzeczywistość: wierzący gromadzili się przy murach, oczekując na pojawienie się i błogosławieństwo Patriarchy. Jednak te rzeczywiste fakty historyczne okazały się praobrazem oddawanej mu w Kościele czci oraz późniejszego wyniesienia na ołtarze. W kompozycji jest on przedstawiony jako kanonizowany święty, a modlący się ludzie wyobrażają kanonizujący go Kościół ${ }^{60}$.

Symbolem pierwszych lat prześladowań bolszewickich, skierowanych nie tylko przeciw Kościołowi, lecz także opozycji politycznej, stał się Sołowiecki Obóz Specjalnego Przeznaczenia (Sołowieckij Łagier Osobogo Naznaczenija, w skrócie SŁON), istniejący w latach 1923-1933 na miejscu Klasztoru Sołowieckiego ${ }^{61}$. Był on miejscem, w którym wyjątkowo licznie umieszczano prawosławne duchowieństwo oraz hierarchów. W roku 1926 jednocześnie przebywało na Wyspach aż 24 biskupów $^{62}$. Szczególne znaczenie Archipelagu dla Rosyjskiego Kościoła Prawosławnego jest związane również z faktem, że na więzienie został wybrany ważny dla historii Kościoła klasztor, którego budynki sakralne - skity i cerkwie - władze radzieckie przerobiły na więzienie i karcer. Ponadto w potocznym przeświadczeniu cały sy-

\footnotetext{
59 Икона собора новомучеников...

60 Ibidem.

61 A. Applebaum, Gułag, Warszawa 2005; D. Tołczyk, Gułag w oczach Zachodu, Warszawa 2009.

62 В. Цыпин, История Русской Православной Церкви. 1917-1990, Москва 1994, s. 81.
} 
stem Gułagu został wypracowany właśnie na Wyspach, dlatego na początku lat dziewięćdziesiątych wielu aktorów pamięci ${ }^{63}$ było zainteresowanych włączeniem historii Archipelagu w swoją opowieść - interpretację represji sowieckich. To dlatego Wyspy Sołowieckie mają tak szczególne znaczenie w dyskursie nowego męczeństwa ${ }^{64}$. W 2006 roku Olga Klodt-Wołodina napisała oddzielną ikonę Soboru Świętych Męczenników Sołowieckich, na której przedstawiono prawie 70 męczenników:

[...] duchowieństwo i wiernych, którzy znaleźli się w Sołowieckim Obozie Specjalnego Przeznaczenia, miejsca ich aktów męczeńskich, najważniejsze wydarzenia w historii łagru i odrodzonego później Klasztoru Sołowieckiego ${ }^{65}$.

Klejmo na ikonie Nowych Męczenników i Wyznawców Rosyjskich zostało zbudowane według odmiennej logiki. Nie przedstawiono tutaj wszystkich nowych męczenników, którzy zginęli na Wyspach, jak w przypadku wspomnianej powyżej ikony Soboru, lecz konkretne miejsca znajdujące się na Archipelagu, które są symbolami jego łagrowej historii. Tak więc ukazanie świętych zamkniętych we wnętrzu klasztoru nawiązuje do utworzenia w nim więzienia. Z lewej strony przedstawiono cerkiew Wniebowstąpienia znajdującą się na Górze Sekirnej na wyspie Wielka Sołowiecka, którą zamieniono na karcer, oraz schody, z których zrzucano więźniów ${ }^{66}$. Z kolei po prawej stronie zobrazowano górę Golgotę na wyspie Anzer, gdzie był więziony i zginął arcybiskup woroneski Piotr (Zwieriew), który przez pewien czas był duchowym przywódcą prawosławnego kleru przetrzymywanego na Sołowkach. W roku 1928 przeniesiono go na wyspę Anzer, gdzie zachorował na tyfus i 7 lutego 1929 roku zmarł. Na ikonie wyobrażono go jako spoczywającego w ziemi, w czym można widzieć nawiązanie do jednego z przedstawień św. Eleazara Anzerskiego, pustelnika i założyciela skitu na wyspie Anzer. Przedstawiono tu również brzozę, która ma kształt krzyża, przez co jest uznawana za znak postawiony męczennikom przez samego Boga.

Wybór tych konkretnych miejsc i symboli, które częściowo mają potwierdzenie w faktach historycznych, częściowo zaś są legendą (schody na Górę Sekirną), jednak silnie zakorzenioną i działającą na wyobraźnię społeczną, pełni ważną funkcję. Jak czytamy w opisie ikony:

Stworzono nową ikonografię Wysp Sołowieckich, co było spowodowane nowymi czynami świętych sołowieckich z niedawnej przeszłości. Rozszerzająca się ku górze przestrzeń ziemi

${ }^{63}$ Aktor pamięci to termin używany przez badaczy pamięci do określenia osoby zaangażowanej $\mathrm{w}$ proces upamiętniania wydarzenia z przeszłości. Aktorami pamięci są inicjatorzy pomników, kuratorzy wystaw historycznych, architekci i artyści zaangażowani w tworzenie miejsc pamięci, ale również urzędnicy państwowi inicjujący i nadzorujący powstanie miejsc pamięci, osoby duchowne i świeckie zaangażowane w tworzenie znaków przeszłości (por. Bogumił 2012).

${ }^{64}$ Z. Bogumił, The Solovetski Islands and Butovo...

${ }_{65}$ В Соловецкий монастырь прибыла икона новомучеников и исповедников Соловецких, http://www.pravoslavie.ru/16700.html [dostęp: 18.03.2016].

${ }^{66}$ Informacja o tym, że więźniów zrzucano ze schodów, pojawia się u Sołżenicyna w Archipelagu Gułag. W czasie wycieczek po terytorium Góry Sekirnej można usłyszeć tę historię. Według Memoriału jest to tylko legenda, nie potwierdzona żadnymi dokumentami i bezpośrednimi wspomnieniami. Z. Bogumił, Pamięć Gutagu, s. 134. 
połączona jest z przedstawieniami wzniesień na wyspach. To specyficzny dla ikony sposób łączenia różnych planów, który pozwala na stworzenie pełniejszego „obrazu przestrzeni”, w danym przypadku - wysp z ich najważniejszymi punktami charakterystycznymi - i zmieszczenie go na dostępnej płaszczyźnie ${ }^{67}$.

Mimo ogromu represji, które uderzyły w Rosyjski Kościół Prawosławny w ciągu pięciu pierwszych lat po rewolucji październikowej (szacuje się, że dotknęły one około 20 tysięcy osób, z czego ponad połowa poniosła śmierćc8 ${ }^{6}$ i którym towarzyszyły podsycane przez władze wewnętrzne podziały i rozłamy ${ }^{69}$, największa fala prześladowań miała dopiero nadejść w latach trzydziestych. Pospiełowski podaje liczbę co najmniej 30-35 tysięcy aresztowanych lub zamordowanych duchownych, szacując jednak, iż mogło ich być nawet 50 tysięcy ${ }^{70}$. Nowe prześladowania nastąpiły w latach 1929-1934, przede wszystkim zaś w okresie Wielkiego Terroru 1937-1938, kiedy to w ZSRR ludność dotknęły masowe represje. Robert Conquest podaje całościowe dane, pisząc, że aresztowano około 7-8 milionów osób, trójki NKWD rozstrzelały około półtora miliona, w łagrach zmarło około 2 milionów ${ }^{71}$. Prześladowaniom poddano również prawosławnych duchownych i wiernych. Do wydarzeń tych lat nawiązują trzy klejma na ikonie Nowych Męczenników i Wyznawców: drugie, przedstawiające cierpienia i śmierć metropolity Piotra (Polańskiego), strażnika tronu patriarszego (locum tenens); dziewiąte, poświęcone męczennikom zamordowanym na poligonie w Butowie pod Moskwą; piętnaste, na którym wyobrażono rozstrzelanie metropolity Cyryla (Smirnowa). W ten sposób upamiętniono zarówno męczeństwo masowe, jak i indywidualne.

Poligon butowski jest symbolem masowych rozstrzeliwań, głównie z okresu Wielkiego Terroru lat 1937-1938, choć egzekucje odbywały się tu jeszcze w latach pięćdziesiątych, do śmierci Stalina. Jak pisze Igor Garkawyj, dyrektor Memorialnego Centrum Nauki i Edukacji „Butowo”: „wiadomo z dokumentów, że tylko w okresie od

67 Икона собора новомучеников...

68 Н.Е. Емельянов, Оценка статистики гонений на Русскую Православную Церковь в ХХ веке, http://www.orthedu.ru/ch_hist/hi_rpz/9073ots.htm [dostęp: 22.07.2015]. Uczeni mają problemy z ustaleniem dokładnej liczby ofiar, różnice w ich oszacowaniu są bardzo duże. O skali rozbieżności może świadczyć przykład podany przez ihumena Damaskina (Orłowskiego): według jednych danych w 1918 roku było rozstrzelanych 827 duchownych, zaś według innych - aż 3 tysiące! (Дамаскин (Орловский), Гонений на Русскую Православную Церковь в СССР, https:/orthodoxy33.wordpress. com/2011/11/15/nssr/ [dostęp: 22.07.2015].

$69 \mathrm{Na}$ ten temat zob. Д.В. Поспеловский, op.cit., s. 62-102, 119-156.

70 Ibidem, s. 170-171. Mitrofanow, na podstawie danych Komisji do Spraw Rehabilitacji Ofiar Represji Politycznych przy Prezydencie Federacji Rosyjskiej, pisze o ponad 100 tysiącach rozstrzelanych (Г. Митрофанов, Канонизация новомучеников... Podobne liczby podają również Jemieljanow (250 tysięcy represjonowanych, w tym 105 tysięcy zamordowanych; Н.Е. Емельянов, Оиенка статистики гонений) oraz Zubow (205 tysięcy represjonowanych, 110 tysięcy zamordowanych; История России. ХХ век: 1894-1939, А. Зубов (ред.), Москва 2011, s. 878, 964).

${ }^{71}$ Oszacowanie liczby ofiar jest bardzo trudne ze względu na niepełne dane, stąd duże rozbieżności. Przykładowo, w Historii Rosji w XX wieku pod redakcją A. Zubowa przytoczone są dane przekazane przez rosyjską prokuraturę i MSW, z których wynika, że represje stalinowskie dotknęły ponad $50 \mathrm{mi-}$ lionów osób, co jest jednak liczbą zawyżoną, gdyż zawiera również ponowne aresztowania tej samej osoby (История России. ХХ век, s. 967). Zob. też R. Conquest, Wielki terror, tłum. W. Jeżewski, Warszawa 1997. 
8 sierpnia 1937 do 19 października 1938 roku rozstrzelano tu i pochowano 20760 osób" "72. Mimo że tego typu miejsc masowych mordów jest na terenie Federacji Rosyjskiej znacznie więcej, wyjątkowość Butowa polega na tym, że dzięki odnalezieniu dokumentów $\mathrm{z}$ archiwum FSB udało się ustalić imiona i nazwiska spoczywających tu ofiar Wielkiego Terroru ${ }^{73}$. Ważne znaczenie ma też fakt, że wśród rozstrzelanych i pogrzebanych na terenie poligonu znajduje się aż 332 kanonizowanych świętych. Jak podkreślił w wywiadzie ojciec Kiriłł, proboszcz butowskiej parafii, to miejsce kultu, gdzie realnie znajdują się relikwie świętych:

[...] czy są [...] podobne miejsca, jak Butowo, gdzie znajdowałaby się taka ilość relikwii świętych? My mamy 332 świętych kanonizowanych, których relikwie tu spoczywają. W Kościele pierwszych wieków wiadomo, że tam zabijano wiele tysięcy chrześcijan, ale nie znamy miejsc ich pochówku, gdzie spoczywają ich święte szczątki ${ }^{74}$.

$\mathrm{Na}$ ikonie święci przedstawieni są w czterech grupach, do dwóch z nich strzelają zabójcy, dwie zaś przedstawiają ciała już zamordowanych, spoczywających w jamach. Jak podkreślono w opisie ikony:

[...] imion nie podano, gdyż kompozycja ma na celu ukazanie masowego cierpienia i śmierci nieznanych świętych. [...] Pośrodku na tle spokojnych zielonych górek znajduje się figura pewnego starca-kapłana w jasnożółtych szatach, za nim przedstawiono jeszcze dwoje w ciemnoczerwonych i różowych strojach. W środkowej postaci najbardziej podkreślono śmiałość i męstwo świadectwa oddania życia za wiarę prawosławną. Starzec w jasnych szatach błogosławi oprawców. [...] Kolor oznacza ich świętość, przejście do życia wiecznego ${ }^{75}$.

Męczennikami wielkiego terroru są również przedstawieni na klejmach 2 i 15 metropolici Piotr (Polański) oraz Cyryl (Smirnow), którzy w roku 1924 znaleźli się na liście trzech ewentualnych następców wyznaczonych przez patriarchę Tichona na wypadek śmierci lub aresztowania (trzecim był metropolita Agatangel (Prieobrażenski), kanonizowany w roku 2000 jako wyznawca). Ponieważ w chwili śmierci Tichona metropolita Piotr jako jedyny pozostawał na wolności, to on objął stanowisko patriarszego locum tenens, jednak nie na długo: już po kilku miesiącach, w grudniu 1925 roku, został aresztowany i skazany na trzy lata zesłania w region północnego Uralu, za kręgiem polarnym. Karę kilkakrotnie przedłużano, zaś w październiku 1937 roku metropolita Piotr został skazany na śmierć i rozstrzelany. Jego kanonizacja odbyła się w roku 1997, a wyjątkowa cześć oddawana mu przez wiernych wynika zarówno z jego długotrwałych cierpień, jak i z faktu, że był jednym $\mathrm{z}$ wielu duchownych, którzy przyjmowali święcenia bezpośrednio po dojściu do władzy bolszewików, w momencie gdy taka decyzja była wyrazem męstwa i narażała

72 И. Гарькавый, Мемориальные традиции: истоки и практика, „60 параллель” 2010, nr 1, http://www.intelros.ru/readroom/60_paralel/1-36-2010/6392-memorialnye-tradicii-istoki-i-praktika. html [dostęp: 15.03.2016].

73 K. Rousselet, Butovo la création d'un lieu de pèlerinages sur une terre de massacres, „Politix” 2007, nr 77, s. 55-78.

74 Wywiad z o. Kiriłłem, 11 maja 2014 r.

75 Икона собора новомучеников... 
na prześladowania ${ }^{76}$. Na klejmie ikony jest on przedstawiony dwa razy: na górze podczas swego długoletniego więzienia, na dole zaś w chwili rozstrzelania. Według zamysłu autorów takie przedstawienie podkreśla

[...] królewski charakter świętości. Ten znajdujący się nad sceną zabójstwa obraz wyjątkowo dobitnie na tle innych kompozycji pokazuje triumf życia wiecznego. Na to, co tymczasowe uwięzienie na dalekiej północy w wiosce $\mathrm{He}$ - nakłada się to, co wieczne: triumf nad śmiercią ${ }^{77}$.

Metropolita Cyryl (Smirnow), wyobrażony na ostatnim, 15 klejmie ikony, był przedstawicielem wewnątrzkościelnej opozycji wobec ugodowej polityki metropolity Sergiusza (Stragorodskiego), który po aresztowaniu metropolity Piotra objął (na podstawie sporządzonej przez niego listy) stanowisko zastępcy locum tenens patriarchy, a w roku 1927, najpewniej pod presją GPU i mając nadzieję na uchronienie Rosyjskiego Kościoła Prawosławnego od dalszych prześladowań, wydał kontrowersyjną deklarację lojalności wobec władzy radzieckiej ${ }^{78}$. Spowodowała ona wypowiedzenie posłuszeństwa metropolicie Sergiuszowi przez część hierarchów (między innymi metropolitę Cyryla (Smirnowa)) i w rezultacie kolejne podziały w Kościele. Doszło przede wszystkim do ostatecznego oderwania się Rosyjskiego Kościoła Prawosławnego poza Granicami Rosji, utworzonego w roku 1922 przez duchowieństwo, które znalazło się na emigracji ${ }^{79}$, a także do pojawienia się w samym ZSRR kilku grup będących w opozycji wobec metropolity Sergiusza. Z czasem ruch ten zaczęto określać wspólną nazwą ,,cerkwi katakumbowej”, choć to określenie dość niedokładne, oznaczające wiele różnorodnych zjawisk, często o charakterze politycznym ${ }^{80}$.

Metropolita Cyryl - podobnie jak wielu hierarchów i duchownych w latach dwudziestych i trzydziestych, niezależnie od ich stosunku do metropolity Sergiusza - był kilkakrotnie aresztowany, po czym w 1937 roku rozstrzelany wraz z grupą innych duchownych pod Szymkentem w Kazachstanie. To właśnie męczeńska śmierć wyobrażona jest na ikonie. W opisie ikony czytamy o znaczeniu tego przedstawienia:

To akord końcowy, godnie wieńczący dramatyczną suitę kompozycji, które po raz pierwszy w sztuce cerkiewnej w sposób całościowy przedstawiają wyjątkowe w historii świadectwo Kościoła rosyjskiego w naprawdę śmiertelnej walce z siłami piekła, które nie były w stanie pokonać Bożych świętych ${ }^{81}$.

Po roku 1938 władza kontynuowała represje wobec Kościoła prawosławnego. W ich rezultacie doprowadzono do sytuacji, w której w 1939 roku urząd sprawowało

${ }^{76}$ Wśród duchownych konsekrowanych w latach 1918-1920 można wymienić - oprócz metr. Piotra - także teologa o. Sergiusza Bułgakowa (wyświęcony w 1918), pisarza i literaturoznawcę o. Sergiusza Durylina (wyświęcony w 1920 r.) czy też wykładowcę i popularyzatora ruchu skautowego w Rosji bpa Bazylego Prieobrażenskiego (konsekrowany w 1920).

77 Икона собора новомучеников...

78 Д.В. Поспеловский, op.cit., s. 116.

79 История России. ХХ век, s. 832-833.

${ }^{80}$ Próbę uporządkowania problematyki związanej z ,cerkwią katakumbową”, przedstawienia jej struktury i etapów działalności podjęła Maria Fiedienko (М. Феденко, Феномен катакомбной церкви, „Кифа” 2015, nr 194, s. 1, 4). Zob. też Д.В. Поспеловский, op.cit., s.173-176.

${ }^{81}$ Икона собора новомучеников... 
jedynie czterech hierarchów (pozostali zostali zamordowani lub znajdowali się w łagrach i na zesłaniu), a w całej Rosji było otwartych jedynie około 350 cerkwi, gdzie posługę duszpasterską wypełniało nie więcej niż 500 duchownych $^{82}$. Zmiana polityki Stalina wobec Kościoła, która nastąpiła po roku 1941, zdaniem większości historyków została spowodowana początkowymi klęskami Armii Czerwonej i ofensywą III Rzeszy, a także patriotyczną postawą Rosyjskiego Kościoła Prawosławnego z jednej strony - i masowym odrodzeniem religijnym na terenach zajętych przez faszystów - z drugiej. Jak podkreśla Michaił Szkarowski, represje wobec wierzących nie ustały całkowicie, były jednak stosowane przede wszystkim wobec przedstawicieli cerkwi katakumbowej ${ }^{83}$.

Mimo że po roku 1938 władze kontynuowały prześladowania wierzących, nie zostały one wyobrażone na ikonie, podobnie jak wśród świętych kanonizowanych przez Rosyjski Kościół Prawosławny nie ma ofiar represji powojennych, takich jak na przykład zmarły w więzieniu w 1971 roku prawosławny obrońca praw człowieka Boris Tałantow czy też anonimowy parafianin zastrzelony w 1959 przez milicję podczas protestu przeciw zamknięciu Klasztoru Reczulskiego w okolicach Kiszynio$\mathrm{wa}^{84}$. Jak podkreśla Ilja Semienienko-Basin, kwestia granic chronologicznych zjawiska nowego męczeństwa ma zasadnicze znaczenie dla określenia badanego konceptu. Dla duchowieństwa Rosyjskiego Kościoła Prawosławnego poza Granicami Rosji ważne było podkreślenie ciągłości prześladowań, nierozerwalnie związanych z władzami komunistycznymi, przedstawienie represji jako wydarzeń apokaliptycznych i przejawu odwiecznej walki dobra ze złem. Z kolei postawienie cezury w połowie wieku (jak w przypadku kanonizacji Rosyjskiego Kościoła Prawosławnego) przenosi akcent na uwarunkowania historyczne i sprawia, że męczennicy są postrzegani jako ofiary zmiennego kursu politycznego czy wręcz konkretnych działaczy partyjnych ${ }^{85}$. Pozwala to, jak się wydaje, na zdjęcie odpowiedzialności z przedstawicieli obecnych rosyjskich władz, z których wielu, jak wiadomo, rozpoczynało swą karierę jeszcze w okresie ZSRR. Umożliwia też pominięcie milczeniem drażliwej kwestii współpracy hierarchii kościelnej z radziecką służbą bezpieczeństwa.

Jednocześnie należy zwrócić uwagę, że wydarzenia przedstawione na ikonie są ograniczone akurat do okresu 1917-1937, czyli tego, z którym współcześni historycy rosyjscy mają największy problem interpretacyjny. Lata poprzednie należą do historii Imperium Rosyjskiego, zaś wydarzenia po 1941 roku są włączane w pozytywną historię ZSRR. Problem stanowią wydarzenia, jakie rozegrały się między rokiem 1917 i 1937, datami symbolizującymi dwa momenty najcięższych prześladowań Kościoła, ale również dramatów doświadczanych przez zwykłych obywateli. Na ikonie te dwie

\footnotetext{
82 Д.В. Поспеловский, оp.cit., s. 168, 183; История России. ХХ век, s. 951-952.

83 М. Шкаровский, Сталинская религиозная политика и Русская Православная Церковь в 1943-1953 годах, „Acta Slavica Iaponica” 2009, nr 27, s. 10.

${ }^{84}$ В. Козлов, Неизвестный СССР. Противостояние народа и власти. 1953-1985, Москва 2006, s. 268. Wśród kanonizowanych świętych jest co prawda dwóch kapłanów, którzy zmarli w latach siedemdziesiątych (archimandryta Leoncjusz Stasiewicz i o. Piotr Czelcow), jednak byli oni represjonowani wcześniej, od 1955 r. zaś obaj zostali zwolnieni z obozów i do końca życia pełnili posługę w wiejskich parafiach (И.В. Семененко-Басин, Святость в русской православной..., s. 191-192).

${ }^{85}$ И.В. Семененко-Басин, Святость в русской православной..., s. 192-193.
} 
daty są połączone, za pomocą miejsc-symboli represji tych dwóch okresów, Wysp Sołowieckich i utworzonego tam SŁON-u, którego powstanie było bezpośrednim rezultatem zdarzeń, jakie nastąpiły po wybuchu rewolucji. To przedstawienie znajduje się na samej górze lewego pasa klejm. Z kolei pas ten zamyka umieszczone w dolnym lewym rogu Butowo, miejsce-symbol Wielkiego Terroru. W innej swojej publikacji Zuzanna Bogumił pokazuje, że takie przedstawienie pełni ważną funkcję, gdyż w sposób mistyczny łączy ze sobą obydwa miejsca ${ }^{86}$. Tutaj warto dodać, że obydwa klejma nadają również sens interpretacji zaproponowanej przez ikonę, ich ułożenie określa bowiem kierunek czytania ikony, przez co rozkładają one akcenty i organizują narrację o nowym męczeństwie.

\section{Zakończenie}

Ikona Soboru Świętych Nowych Męczenników i Wyznawców Rosyjskich jest wizualną opowieścią o prześladowaniach Rosyjskiego Kościoła Prawosławnego w latach 1917-1938. Jednocześnie stanowi czytelną interpretację znaczenia tych wydarzeń dla współczesnego Kościoła. Sposób przedstawienia na ikonie świętych oraz kompozycja scen wyobrażających ich męczeństwo wysuwają na pierwszy plan wzniosłość, wyjątkowość tych postaci, akcentują ich chwałę, unieważniając jednocześnie pytania o przyczyny rewolucji i prześladowań Kościoła czy też o sprawców popełnionych zbrodni. Zgodnie z tą narracją liczba męczenników jest przede wszystkim świadectwem wielkości duchowej Rosji, która wydała tak obfity plon świętości w czasach próby wiary, zaś zbrodniarze stają się jedynie bezosobową emanacją zła. W rezultacie nowe męczeństwo nie wzywa do osądzenia sprawców i rozrachunku z przeszłością, ale wprost przeciwnie - pozwala na włączenie okresu represji sowieckich w opowieść o historii Rosji, nadając temu okresowi status czasu próby, który zaktualizował wyjątkowość dziejową państwa, tak silnie wyrażoną w kulturowym wyobrażeniu Rosji jako Trzeciego Rzymu.

W rezultacie spośród istniejących narracji historycznych o wydarzeniach z lat 1917-1937 ikona Soboru Świętych Nowych Męczenników i Wyznawców Rosyjskich wydaje się najbardziej kompletna. Jak pisał Frank Ankersmit, „najlepsza narracja historyczna to taka, gdzie proponowane ujęcie całości jest najlepiej wyrażone"87. Ponadto powinna to być opowieść metaforyczna, wykorzystująca różne figury retoryczne, dzięki czemu dostarcza zarówno doświadczenia traumy, jak i wzniosłości, umożliwiając „dotknięcie świata takim, jakim jest”"88. Wszystkie te elementy obecne są na przeanalizowanej w niniejszym artykule ikonie Soboru Świętych Nowych Męczenników i Wyznawców Rosyjskich, dzięki czemu, jak się wydaje, ma ona szanse na ukazanie kierunku interpretacji historii państwa radzieckiego w okresie przedwojennym.

\footnotetext{
${ }^{86}$ Z. Bogumił, The Solovetski Islands...

${ }^{87}$ F. Ankersmit, Narracja, Reprezentacja, Doświadczenie: studia z teorii historiografii, E. Domańska (red.), Kraków 2004, s. 43.

${ }^{88}$ E. Domańska, Miejsce Franka Ankersmita w narratywistycznej filozofii historii [w:] Narracja, Reprezentacja, Doświadczenie..., s. 21.
} 
Jak już wspomniano, kanonizowani przez Rosyjski Kościół Prawosławny święci zostali zamordowani właśnie w latach 1917-1938, a więc w okresie, którego historyczne interpretacje w ciągu ostatnich stu lat uległy radykalnej przemianie. Rewolucję bolszewicką brytyjski historyk Orlando Figes określił słowami „human event of complicated individual tragedies" ${ }^{89}$. Z kolei okres Wielkiego Terroru jest powszechnie określany jako czas traumy dla życia całego społeczeństwa ${ }^{90}$. Dla Rosyjskiego Kościoła Prawosławnego te dwa wydarzenia stają się kluczowymi momentami najnowszej historii kraju, co jest doskonale widoczne w przedstawieniach zawartych na klejmach. Jednocześnie wyraźnie widać, że dominują tu sceny męczeństwa hierarchów cerkiewnych okresu wojny domowej, mimo że Kościół w swojej interpretacji przeszłości wyraźnie podkreśla znaczenie świadectwa zwykłych ludzi i niższych rangą duchownych. Na klejmach nie przedstawiono takich znanych postaci, jak ks. Ioann Koczurow, pierwsza ofiara represji, czy o. Sergiusz Mieczew, proboszcz popularnej wśród inteligencji moskiewskiej parafii św. Mikołaja na ulicy Marosiejka, założyciel działającego w latach dwudziestych ruchu małych wspólnot. Znalazło się za to na nich wielu hierarchów, których kult wcale nie aż tak żywo rozwija się współcześnie. To pokazuje, że Kościołowi prawosławnemu zależy, aby nowe męczeństwo kojarzyło się przede wszystkim z ogromną ofiarą samego Kościoła i jego zwierzchników, złożoną $\mathrm{w}$ walce ze złem, a nie $\mathrm{z}$ cierpieniem niewinnych ludzi. Ikona przedstawia Kościół jako ten, który jako jedyny nie ugiął się przed władzą komunistyczną, za co spotkały go najcięższe represje. Jednocześnie podkreśla ona, że tradycyjny mariaż Kościoła i władzy jest fundamentem rosyjskiego, prawosławnego społeczeństwa. Wszelka wina za wybuch rewolucji jest zdjęta z cara Mikołaja II, który, podobnie jak Kościół prawosławny, zapłacił najwyższą cenę za zbłądzenie narodu. Dlatego dwa z 15 klejm przedstawiają cierpienie rodziny carskiej: szóste św. Elżbiety i ósme Mikołaja II z żoną i dziećmi. Warto podkreślić, że wszystkie te postaci zostały również przedstawione na średniku ikony. Jak czytamy w jej opisie:

Innego miejsca dla przedstawienia Carskich męczenników nie można było wyznaczyć. Znajdują się w centrum, gdyż personifikują błogosławioną przez Boga zasadę władzy zwierzchniej i porządku, który przeciwstawia się chaosowi ${ }^{91}$.

Rodzina carska znajduje się przy tym poniżej hierarchów duchownych, co podkreśla prymat władzy kościelnej nad ziemską i stanowi nawiązanie do bizantyjskiej idei symfonii. W tym wymiarze ikona wyraźnie wskazuje na akceptację tradycyjnego dla rosyjskiego prawosławia związku władzy świeckiej i kościelnej.

Warto zwrócić uwagę, że na klejmie przedstawiającym zbiorowe męczeństwo na Wyspach Sołowieckich w sposób szczególny zaznaczono cierpienie abpa Piotra (Zwieriewa), który był nieformalnym liderem duchowieństwa przebywającego na Sołowkach w okresie SŁON-u, w przypadku Butowa zaś nie wyróżniono metr. Serafina (Cziczagowa), chociaż hierarcha ten jest obecnie jednym z najbardziej

\footnotetext{
${ }^{89}$ O. Figes, A People's Tragedy: The Russian Revolution 1891-1924, London 1996, s. XIX.

${ }^{90}$ S. Fitzpatrick, Everyday Stalinism: Ordinary Life in Extraordinary Times: Soviet Russia in the 1930s, New York City 2000.

${ }^{91}$ Икона собора новомучеников и исповедников...
} 
rozpoznawalnych i czczonych nowych męczenników butowskich. Można to wytłumaczyć faktem, że kiedy w roku 2000 ikona Soboru Świętych Nowych Męczenników i Wyznawców Rosyjskich była pisana, znaczenie nowego męczeństwa dla Rosyjskiego Kościoła Prawosławnego dopiero się kształtowało. W tym czasie w zasadzie nie istniał jeszcze kult metr. Serafina (Cziczagowa), podobnie jak licznych innych świętych męczenników. Wielu duchownych nie doceniało także znaczenia ich męczeństwa. Dlatego przy pisaniu ikony Rosyjski Kościół Prawosławny blisko współpracował z Kościołem poza Granicami Rosji, a na rozumienie męczeństwa wyobrażonych na ikonie świętych ogromny wpływ miały żywoty Michaiła Polskiego wydane w Stanach Zjednoczonych na przełomie lat czterdziestych i pięćdziesiątych. Dopiero po kanonizacji świętych nastąpił intensywny proces tworzenia miejsc ich kultu, takich jak: Butowo, Ganina Jama, Ałapajewsk, Cerkiew na Krwi w Jekaterynburgu.

Znaczenie nowego męczeństwa dla rosyjskiego prawosławia jest cały czas kształtowane i mimo że jego rozumienie i interpretacja mogą być różne w różnych grupach wiernych i wewnątrzkościelnych frakcjach, to jednak jego wydźwięk w oficjalnym nurcie nabiera coraz bardziej triumfalistycznego charakteru. Męczeństwo jest postrzegane jako dowód wielkości Rosji i Rosyjskiego Kościoła Prawosławnego. Jak pisze Semienienko-Basin, „Rosja w sferze idealnej, w świętości [...] wygrała swój XX wiek. Co więcej, Rosja w soborze swych świętych jest przedstawiona jako święte imperium, kontynuatorka teokratycznej linii bizantyjskiej"92, co daje Kościołowi Rosyjskiemu przewagę w symbolicznym kapitale nad Patriarchatem Konstantynopolskim, tradycyjnym rywalem w walce o wpływ na światowe prawosławie.

Taka interpretacja jest bliska stanowisku władz świeckich oraz państwowej interpretacji przeszłości Rosji i ZSRR ${ }^{93}$. Rezultat tej współpracy władz i Kościoła stanowi budowa z inicjatywy biskupa Tichona (Szewkunowa), spowiednika Władimira Putina, na Łubiance w centrum Moskwy monumentalnej cerkwi pod wezwaniem Nowych Męczenników i Wyznawców Rosyjskich na Krwi. Jak tłumaczył biskup Tichon:

Jak ją widzę? [...] Jako świątynię-pomnik, poświęconą zwycięstwu Pana Jezusa Chrystusa i Jego uczniów, świętych nowych męczenników, nad mocami piekielnymi, które powstały przeciw naszemu Kościołowi, naszej Ojczyźnie w tragicznym, ale też wielkim dla Rosji wieku XX. To właśnie będzie główny motyw przewodni naszej świątyni: jaśniejące zwycięstwo ducha, zwycięstwo Kościoła nad planami jego zniszczenia, podporządkowania sobie ludzi ${ }^{94}$.

Uroczysta konsekracja świątyni odbędzie się w jubileuszowym 2017 roku przy okazji obchodów setnej rocznicy wybuchu rewolucji lutowej - 25 maja 2017 roku. Takie rozumienie okresu represji sprawia, że reżim Putina coraz chętniej wspiera starania Kościoła w rozwoju kultu Nowych Męczenników i Wyznawców. Ta bowiem

${ }_{92}$ И.В. Семененко-Басин, Святость в русской православной..., s. 165.

${ }^{93}$ Christensen wyraźnie pokazuje, że interpretacja kościelna coraz mocniej wychodzi naprzeciw oczekiwaniom władz i że dyskurs nowego męczeństwa ulega przeobrażeniom mającym na celu zyskanie poparcie Kremla. K.H. Christensen, op.cit.

${ }^{94}$ Наша задача-сделать историю актуальной, https://izborsk-club.ru/9714 [dostęp: 7.02.2017]. 
interpretacja przeszłości nie oskarża władzy o popełnienie zbrodni, ale wskazuje na niesprecyzowanego wroga zewnętrznego, który doprowadził ludzi do zbłądzenia, co podkreślił biskup Tichon w ostatnich słowach swojej wypowiedzi.

Mimo silnego związku nowego męczeństwa z historią, co było pokazane w naszej analizie ikony, następuje jego ponowna dehistoryzacja, wpisanie w ponadczasową walkę dobra i zła w rosyjski mit Moskwy jako Trzeciego Rzymu, przez co dokonuje się oddzielenie od konkretnych okoliczności historycznych. Postępuje więc mitologizacja nowego męczeństwa i jednocześnie jego schematyzacja, tak typowa zresztą dla działalności hagiograficznej Kościoła w przeszłości. Mimo wysiłków niektórych środowisk prawosławnych i świeckich badaczy przeszłości, w powszechnej świadomości utrwalają się właśnie te zmitologizowane schematy. W ciągu ostatnich 100 lat historia zatoczyła koło. Ludzie, których władza bolszewicka mordowała, tłumacząc, że utrudniali budowę państwa komunistycznego, obecnie są ponownie wykorzystywani w celu nadania sensu represjom władz sowieckich.

\section{Bibliografia}

Ankersmit F., Narracja, Reprezentacja, Doświadczenie: studia z teorii historiografii, E. Domańska (red.), Kraków 2004.

Applebaum A., Gułag, Warszawa 2005.

Bogumił Z., The Solovetski Islands and Butovo as two „Russian Golgothas”. New Martyrdom as a Means to Understand Russian Repression [w:] (Hi-)Stories of the Gulag. Fiction and Reality, F. Fischer von Weikersthal, K. Thaidigsmann (red.), Heidelberg 2016, s. 133-154.

Bogumił Z., Pamięć Gułagu, Kraków 2012.

Bogumił Z., Wyspy Solowieckie jako „rosyjska Golgota” - o prawosławnym języku mówienia o represjach sowieckich [w:] Konstrukcje i dekonstrukcje tożsamości, t. 1, Wokót religii i jej języka, E. Golachowska, A. Zielińska (red.), Warszawa 2011, s. 307-318.

Charkiewicz J., Kanonizacja nowomęczenników okresu niewoli tureckiej w Kościele prawosławnym i ich znaczenie, „Elpis” 2015, nr 17, s. 43-51.

Charkiewicz J., Kanonizacja świętych w prawosławiu, Warszawa 2014.

Christensen K.H., The Making of the New Martyrs of Russia. Soviet Repression in Orthodox Memory. PhD dissertation, Copenhagen 2015 (manuskrypt udostępniony przez autorkę).

Davis N., A long Walk to Church. A Contemporary History of Russian Orthodoxy, ColoradoOxford 2003.

Domańska E., Miejsce Franka Ankersmita w narratywistycznej filozofii historii [w:] Narracja, Reprezentacja, Doświadczenie: studia z teorii historiografii, Kraków 2004, s. 5-27.

Fedor J., Setting the Soviet Past in Stone: The Iconography of the New Martyrs of the Russian Orthodox Church, „Australian Slavonic and East European Studies” 2014, vol. 28, nr 1-2, s. 121-153.

Figes O., A People's Tragedy: The Russian Revolution 1891-1924, London 1996.

Fitzpatrick S., Everyday Stalinism: Ordinary Life in Extraordinary Times: Soviet Russia in the 1930s, New York City 2000.

Garrard J., Garrard C., Russian Orthodoxy Resurgent. Faith and Power in the New Russia, Princeton-Oxford 2008.

Greene R.H., Bodies Like Bright Stars: Saints and Relics in Orthodox Russia, DeKalb 2010.

Jazykowa I., Świat ikony, tłum. ks. H. Paprocki, Warszawa 1998. 
Lichaczow D., Poetyka literatury staroruskiej, tłum. A. Prus-Bogusławski, Warszawa 1981.

Maszkiewicz M., Mistyka i rewolucja. Aleksander Wwiedeński i jego koncepcja roli cerkwi w państwie komunistycznym, Kraków 1995.

Pawełczyk-Dura K., Kampania otwierania świętych relikwii jako element antycerkiewnej polityki władz komunistycznych, „Studia Religiologica” 2012, nr 3 (45), s. 227-235.

Rousselet K., Butovo la création d'un lieu de pèlerinages sur une terre de massacres, „Politix” 2007, nr 77, s. 55-78.

Sevčenko N.P., The Vita Icon and the Painter as a Hagiographer, „Dumbarton Oaks Paper” 1999, nr 53, s. 149-165.

Tołczyk D., Gułag w oczach Zachodu, Warszawa 2009.

Uspienski L., Teologia ikony, tłum. M. Żurowska, Poznań 1993.

Бычков В.В., Феномен иконы, Москва 2009.

История России. ХХ век: 1894-1939, А. Зубов (ред.), Москва 2011.

Каварнос К., Значение новых мучеников в жизни Православной Церкви, „Православная жизнь" 1999, nr 2 (590), s. 1-12.

Кашеваров А.Н., Православная российская церковь и советское государство (1917-1922), Москва 2005.

Козлов В., Неизвестный СССР. Противостояние народа и власти. 1953-1985, Москва 2006.

Польский М., Новые Мученики Российские, t. 1-2, Jordanville 1949-1957.

Поспеловский Д.В., Русская православная цеерковь в ХХ веке, Москва 1995.

Русская православная церковь и коммунистическое государство 1917-1941. Документь и фотоматериаль, А. Сапов (red.), Москва 1996.

Семененко-Басин И.В., Новомученики российские: содержание термина, „Диалог со временем" 2009, nr 28, s. 367-374.

Семененко-Басин И.В., Святость в русской православной культуре ХХ века. История персонификации, Москва 2010.

Феденко М., Феномен катакомбной иееркви, „Кифа” 2015, nr 194, s. 1, 4.

Цыпин В., История Русской Православной Церкви. 1917-1990, Москва 1994.

Шкаровский М., Сталинская религиозная политика и Русская Православная Церковь в 1943 1953 годаx, „Acta Slavica Iaponica” 2009, nr 27, s. 1-27.

\section{Spis wywiadów:}

Wywiady zostały przeprowadzone przez Zuzannę Bogumił metodą wywiadu pogłębionego w trakcie realizacji badań terenowych w Rosji w 2014 roku w ramach grantu NCN N N116 696040. Nagrania i ich transkrypcje znajdują się w archiwum badaczki.

o. Andriej - mnich z klasztoru pw. Spotkania Włodzimierskiej Ikony Matki Bożej w Moskwie. Moskwa, 30 października 2014 roku.

Ihumen Damaskin (Orłowski) - jeden z teoretyków nowego męczeństwa. Autor siedmiotomowego zbioru żywotów nowych męczenników rosyjskich zatytułowanego Męczennicy, wyznawcy i bohaterowie wiary Rosyjskiego Kościoła Prawosławnego XX stulecia (Moskwa 1992-2002). Od 1997 roku prowadzi Regionalną Fundację Społeczną „Pamięć Męczenników i Wyznawców Rosyjskiego Kościoła Prawosławnego". Moskwa, 18 maja 2014 roku.

o. Kiriłł Kaleda - proboszcz parafii pw. Świętych Nowych Męczenników i Wyznawców Rosyjskich w Butowie. Butowo, 11 maja 2014 roku. 